\title{
A $\beta$-Induced Alterations in Membrane Lipids Occur before Synaptic Loss Appears
}

\author{
Michiel Van Bulck ${ }^{1,2, *(\mathbb{C},}$, Nicola Brandt ${ }^{1}$, Ralf A. Claus ${ }^{3} \mathbb{D}$, Markus Gräler ${ }^{3,4}{ }^{(\mathbb{C}}$ and Anja U. Bräuer ${ }^{1,5, *(\mathbb{C})}$ \\ 1 Research Group Anatomy, School for Medicine and Health Science, Carl von Ossietzky University Oldenburg, \\ 26129 Oldenburg, Germany; nicola.brandt@uni-oldenburg.de \\ 2 Department of Experimental Models of Human Disease, Networked Center of Biomedical Research on \\ Neurodegenerative Diseases (CIBERNED), Institute for Biomedical Research A. Sols (CSIC-UAM), \\ 28029 Madrid, Spain \\ 3 Department of Anaesthesiology and Intensive Care Medicine Center for Molecular Biomedicine(CMB), \\ Jena University Hospital, 07745 Jena, Germany; ralf.claus@med.uni-jena.de (R.A.C.); \\ markus.graeler@med.uni-jena.de (M.G.) \\ 4 Centre for Sepsis Control and Care (CSCC), Jena University Hospital, 07745 Jena, Germany \\ 5 Research Centre for Neurosensory Science, Carl von Ossietzky University Oldenburg, \\ 26129 Oldenburg, Germany \\ * Correspondence: michiel.van.bulck@uni-oldenburg.de (M.V.B.); anja.braeuer@uni-oldenburg.de (A.U.B.)
}

check for updates

Citation: Van Bulck, M.; Brandt, N.; Claus, R.A.; Gräler, M.; Bräuer, A.U. A $\beta$-Induced Alterations in Membrane Lipids Occur before Synaptic Loss Appears. Int. J. Mol. Sci. 2022, 23 , 2300. https://doi.org/10.3390/ ijms 23042300

Academic Editor: Anna-Leena Sirén

Received: 17 January 2022

Accepted: 17 February 2022

Published: 19 February 2022

Publisher's Note: MDPI stays neutral with regard to jurisdictional claims in published maps and institutional affiliations.

Copyright: (C) 2022 by the authors. Licensee MDPI, Basel, Switzerland. This article is an open access article distributed under the terms and conditions of the Creative Commons Attribution (CC BY) license (https:// creativecommons.org/licenses/by/ $4.0 /)$.

\begin{abstract}
Loss of active synapses and alterations in membrane lipids are crucial events in physiological aging as well as in neurodegenerative disorders. Both are related to the abnormal aggregation of amyloid-beta $(A \beta)$ species, generally known as amyloidosis. There are two major known human $A \beta$ species: $A \beta_{(1-40)}$ and $A \beta_{(1-42)}$. However, which of these species have more influence on active synapses and membrane lipids is still poorly understood. Additionally, the time-dependent effect of $\mathrm{A} \beta$ species on alterations in membrane lipids of hippocampal neurones and glial cells remains unknown. Therefore, our study contributes to a better understanding of the role of $A \beta$ species in the loss of active synapses and the dysregulation of membrane lipids in vitro. We showed that $A \beta_{(1-40)}$ or $A \beta_{(1-42)}$ treatment influences membrane lipids before synaptic loss appears and that the loss of active synapses is not dependent on the A $\beta$ species. Our lipidomic data analysis showed early changes in specific lipid classes such as sphingolipid and glycerophospholipid neurones. Our results underscore the potential role of lipids as a possible early diagnostic biomarker in amyloidosis-related disorders.
\end{abstract}

Keywords: neurones; glia cells; synapses; A $\beta$ species; membrane lipids; Alzheimers disease; cell-communication

\section{Introduction}

Amyloidosis is used as an umbrella term for rare, serious diseases caused by the deposit of misfolded proteins. In brain tissue, it is characterised by the accumulation of amyloid-beta $(A \beta)$, such as occurs in Alzheimer's disease (AD) [1]. A $\beta$ species are products of a proteolytic cleavage, generated from amyloid precursor protein (APP) by $\alpha$ - or $\beta$-secretase and $\gamma$-secretase activity, and their characteristics have been extensively reviewed [1-3]. However, the presumed neurotoxic effects of the major $A \beta$ species, $A \beta_{(1-40)}$ and $A \beta_{(1-42)}$, under pathological and physiological conditions remain unclear. So far, the molecular and cellular mechanism of $A \beta$ species and their impact on the loss of synaptic sites, as well as on the changes of membrane lipids of brain cells, is poorly understood.

APP has been shown to play a pivotal role in synaptic and neural plasticity [4]. In vitro and in vivo studies have demonstrated that soluble $\mathrm{A} \beta$ species accumulate at the synaptic sites, resulting in disrupted synaptic plasticity and long-term potential [5-8]. However, $\mathrm{A} \beta_{(1-42)}$ is thought to be more aggregation-prone compared to $\mathrm{A} \beta_{(1-40)}$. The aggregation status of $A \beta$ species in senile plaques in $\mathrm{AD}$ is strongly regulated by time and their aggregation affinity $[9,10]$. Therefore, as has been demonstrated in vitro and in vivo, $\mathrm{A} \beta$ species have different influences on the pre- and postsynaptic densities dependent on the 
$A \beta$ concentrations, the chemical structure of $A \beta$ ( $\alpha$-helices or $\beta$-sheets), the time of $A \beta$ treatment, and the $A \beta$ aggregation status [2,11-21]. Previously, it was also shown that glial cells are involved in $A \beta$-induced inflammatory responses and play an important role in $A \beta$ clearance and degradation [22]. In addition, glial activation itself could play a protective role against $A \beta$-induced toxicity on neurones [22].

APP and the cleavage products $A \beta_{(1-40)}$ and $A \beta_{(1-42)}$ have different influences on lipid homeostasis [23]. Major molecular targets for $A \beta$ in the cholesterol and sphingolipid metabolic pathways are 3-Hydroxy-3-methylglutaryl-coenzyme A (HMG-CoA) reductase and sphingomyelinases (nSMase) [23]. $\mathrm{A} \beta_{(1-42)}$ activates nSMase, whereas $\mathrm{A} \beta_{(1-40)}$ suppresses the activity of HMG-CoA reductase, resulting in decreased cholesterol levels. Sphingomyelins (SM) reduce $\gamma$-secretase activity, thus reducing A $\beta$ levels; cholesterol, on the contrary, induces $\gamma$-secretase activity and is responsible for elevated $\mathrm{A} \beta$ levels [23,24]. Inhibition of HMG-CoA reductase is responsible for a reduction of intracellular as well as extracellular $A \beta_{(1-40)}$ and $A \beta_{(1-42)}$ peptides, resulting in elevated levels of cholesterol [25]. Sphingosine-1-phosphate (So1P) has been shown to be protective for neuronal cells, whereas ceramide promotes $A \beta$ biogenesis by influencing the $\beta$-secretase of APP [26]. Ceramides also interfere in the control of many cellular processes, influencing, e.g., $A \beta$ aggregation in physiological and pathological aging processes [27]. Phosphatidylcholines can alter the $A \beta_{(1-40)}$ mediated aggregation, depending on the thickness of the lipid membrane [28]. Charged phospholipid bilayers consisting of phosphatidylcholines and phosphoglycerol showed an increase in $A \beta_{(1-40)}$ fibril formation [29].

In this study, we investigated the direct effect and time-dependent influence of two major human $A \beta$ species on primary hippocampal neurones and on glial cells. Hence, we examined whether the loss of active synapses in primary hippocampal neurones is $\mathrm{A} \beta$-species- and time-dependent in vitro.

Our results show for the first time a detailed lipid profiling in two different types of brain cells, primary hippocampal neurones and glial cells, after $3 \mathrm{~h}(3 \mathrm{~h})$ and $12 \mathrm{~h}(12 \mathrm{~h})$ of $A \beta_{(1-40)}$ and $A \beta_{(1-42)}$ treatment. We established that both $A \beta$ species cause changes in the membrane lipids of primary hippocampal neurones and glial cells after $3 \mathrm{~h}$ and $12 \mathrm{~h}$ of treatment. Interestingly, A $\beta$-induced alterations in membrane lipids occurred prior to the loss of active synapses.

\section{Material and Methods}

\subsection{Animals}

For all experiments, timed-pregnant and postnatal mice were obtained from the central animal facility of the Carl von Ossietzky Universität Oldenburg. The primary hippocampal neurones were derived from C57 BL/ 6 mouse embryos at embryonic stage 18 (E18). These experiments were carried out in accordance with the institutional guidelines for animal welfare and approved by the "Niedersächsisches Landesamt für Verbraucherschutz und Lebensmittelsicherheit" (33.19-45502-04-18/2766). The glial cells were obtained from postnatal day 2 (P2) mouse pups in accordance with the institutional guidelines of German animal welfare $(\S 4)$ for the use of laboratory animals at the Carl von Ossietzky Universität Oldenburg.

\subsection{Primary Hippocampal Neurone Cultures}

Primary hippocampal neurones were prepared from E18 mouse embryos. The hippocampi were dissected and pooled in a $15 \mathrm{~mL}$ falcon tube with HBSS (1X, Phenol red, Thermo Fisher Scientific, Waltham, MA, USA) and stored on ice. Afterward, they were washed twice in HBSS and incubated in $0.25 \%$ trypsin (Gibco, Thermo Fisher Scientific) for $15 \mathrm{~min}$ at $37^{\circ} \mathrm{C}$. The supernatant was then carefully removed and replaced by plating media, containing MEM (Gibco, Thermo Fisher Scientific), supplemented with $0.6 \%$ D-(+)glucose ( $\geq 99.5$, Sigma-Aldrich, Taufkirchen, Germany), $10 \%$ horse serum (Gibco, Thermo Fisher Scientific) and $100 \mathrm{U} / \mathrm{mL}$ penicillin with $100 \mu \mathrm{g} / \mathrm{mL}$ streptomycin (Pan-Biotech, Aidenbach, Germany). They were subsequently triturated with a fire-polished glass pipette 
until neurones were dissociated. Before plating the cells, culture plates and glass coverslips (Marienfeld $12 \mathrm{~mm}$, VWR, Darmstadt, Germany) were coated with $0.2 \mathrm{mg} / \mathrm{mL}$ poly-L-lysine (PLL, P2636-100MG, Sigma-Aldrich) in ortho-boric acid (VWR chemicals, Darmstadt, Germany) buffer ( $\mathrm{pH}$ 8.5) overnight, followed by rinses with cell culture water (USP WFI, Lonza, Biozym, Germany). The dissociated neurones were filtered through a $40 \mu \mathrm{m}$ cell strainer (Greiner Bio-one, Frickenhausen, Germany), and for immunofluorescence, $\sim 3 \times 10^{4}$ neurones were plated into 24 -well plates $\left(\mathrm{TPP}^{\circledR}\right.$ Faust lab Science, Klettgau, Germany). For high-performance thin-layer chromatography (HPTLC) and tandem mass spectrometry (MS/MS) analysis, $\sim 1 \times 10^{6}$ neurones were seeded into $60 \mathrm{~mm}$-diameter petri dishes (Nunclon ${ }^{\mathrm{TM}}$ Delta surface, Thermo Fisher Scientific) containing plating media. Three to four hours after plating, cells were washed twice with $1 \times$ PBS (phosphate-buffered Saline, Thermo Fisher Scientific), incubated, and maintained in Neurobasal A media (Gibco, Thermo Fisher Scientific) supplemented with 0.25\% L-glutamine ( $200 \mathrm{mM}$, Sigma Aldrich, Omnilab, Bremen, Germany), 2\% B27-supplement (50X, Thermo Fisher Scientific) and $100 \mathrm{U} / \mathrm{mL}$ penicillin with $100 \mu \mathrm{g} / \mathrm{mL}$ streptomycin (Pan-Biotech). Hippocampal neurones used for synaptic study and lipid analysis were maintained for 12 days in vitro (DIV) at $37^{\circ} \mathrm{C}, 5 \% \mathrm{CO}_{2}$.

\subsection{Primary Glial Cell Cultures}

Glial cell cultures were prepared from cortical tissue of P2 mouse pups. The brains were dissected and washed twice in HBSS (1X, Phenol red, Thermo Fisher Scientific). After removing the meninges from the brains, cortical tissue was isolated, washed twice in HBSS and incubated with $0.05 \%$ trypsin-EDTA (Gibco, Thermo Fisher Scientific) for $12 \mathrm{~min}$ at $37^{\circ} \mathrm{C}$. The supernatant was then carefully removed and replaced by plating media, consisting of DMEM (high glucose with L-glutamine, $4500 \mathrm{mg} / \mathrm{L}$ D-glucose, $110 \mathrm{mg} / \mathrm{L}$ sodium pyruvate, Gibco, Thermo Fisher Scientific) supplemented with 10\% FBS (Pan-Biotech), 10\% HS (Pan-Biotech) and $100 \mathrm{U} / \mathrm{mL}$ penicillin with $100 \mu \mathrm{g} / \mathrm{mL}$ streptomycin (Pan-Biotech). Tissue was carefully triturated and centrifuged for $1 \mathrm{~min}$ at $20 \times \mathrm{g}$. Supernatant was cautiously transferred to a new falcon tube and centrifuged for $5 \mathrm{~min}$ at $300 \times \mathrm{g}$. The supernatant was discarded and the pellet resuspended in plating media. Before plating, the T75 flask (Sarstedt, Label A, The Netherlands), coated overnight with $0.1 \mathrm{mg} / \mathrm{mL}$ PLL (P2636-100MG, Sigma-Aldrich) in ortho-boric acid (VWR chemicals) buffer ( $\mathrm{pH} 8.5)$, was rinsed three times in MilliQ water. The dissociated glial cells were filtered through a $70 \mu \mathrm{m}$ cell strainer (Corning, VWR, Darmstadt, Germany) and plated into the T75 flasks. After 2-3 days, the culture medium was changed and further maintained in $37^{\circ} \mathrm{C}$ at $5 \% \mathrm{CO}_{2}$. After $10-12 \mathrm{DIV}$, microglia were separated from astrocytes by agitation $(230 \mathrm{rpm})$ at $37^{\circ} \mathrm{C}$ for $3-4 \mathrm{~h}$ for obtaining the microglia. Adherent astrocytes were harvested using $0.25 \%$ trypsin-EDTA for $5 \mathrm{~min}$ in an incubator. Astrocytes were collected and centrifuged at $473 \times g$ for $10 \mathrm{~min}$. The cell pellet was resuspended in plating media consisting of 45.5\% DMEM (high glucose with L-glutamine, $4500 \mathrm{mg} / \mathrm{L}$ D-glucose, $110 \mathrm{mg} / \mathrm{L}$ sodium pyruvate, Gibco, Thermo Fisher Scientific), 45.5\% HAMS-F12 nutrient mix (Gibco, Thermo Fisher Scientific), 8\% FBS (Pan-Biotech), 1\% Pen/Strep (Pan-Biotech), and seeded into $60 \mathrm{~mm}$-diameter Petri dishes (Nunclon ${ }^{\mathrm{TM}}$ Delta surface, Thermo Fisher Scientific).

\subsection{A $\beta$ Treatment}

Human synthetic amyloid-beta $42\left(\mathrm{~A} \beta_{(1-42)}\right.$, Tocris Cat. No 1191, Bio-Techne GmbH, Wiesbaden, Germany) and human synthetic amyloid-beta $40\left(\mathrm{~A} \beta_{(1-40)}\right.$, Tocris Cat. No. 1428, Bio-Techne $\mathrm{GmbH}$ ) were reconstituted in dimethylsulfoxide (DMSO, $(\geq 99.5 \%$, Carl Roth, Karlsruhe, Germany)) to a $250 \mu \mathrm{M}$ stock concentration, sonicated for $10 \mathrm{~min}$, and centrifuged at $13,523 \times g$ at $16{ }^{\circ} \mathrm{C}$ [30]. Finally, the 12 DIV hippocampal primary neurones and glial cells were treated with or without $1 \mu \mathrm{M}$ of $\mathrm{A} \beta_{(1-40)}$ and $\mathrm{A} \beta_{(1-42)}$ for $3 \mathrm{~h}$ and $12 \mathrm{~h}$. 


\subsection{Synaptic Study}

Immunofluorescence

After $3 \mathrm{~h}$ and $12 \mathrm{~h}$ DMSO and A $\beta$ treatment, the conditioned medium was removed and the cultured hippocampal neurones were washed once with warm phosphate buffer saline (PBS (1X), Gibco, Thermo Fisher Scientific), followed by fixation with $4 \%$ paraformaldehyde (PFA, Merck Millipore, Darmstadt, Germany) in PBS (1X) containing $15 \%$ D-(+)-saccharose ( $\geq 99.7 \%$, Carl Roth) at $4{ }^{\circ} \mathrm{C}$ for $10 \mathrm{~min}$. After fixation, the cells were washed three times with PBS (1X) before being permeabilised with $0.1 \%$ triton X-100 (Carl Roth) for three minutes at room temperature (RT). The neurones were then washed three times with PBS (1X) for 10 min while gently shaking on a shaker at RT. The neurones were blocked in PBS (1X) containing 10\% foetal bovine serum (FBS, Pan Biotech) and 1\% normal goat serum (NGS, Vector laboratories, Biozol, Germany) for $1 \mathrm{~h}$ on a shaker at RT. Afterward, they were incubated with two primary antibodies: guinea-pig anti-vesicular glutamate transporter-1 (VGlut-1 (1:200), Synaptic Systems, 135304, Göttingen, Germany) and mouse anti-postsynaptic density protein-95 (PSD-95 (1:1000), clone (7E3-1B8), Thermo Fisher Scientific, MA1-046) overnight on a shaker at $5{ }^{\circ} \mathrm{C}$. After washing the neurones three times with PBS they were incubated with two secondary antibodies: goat anti-mouse Alexa Fluor 488 (1:1500, Molecular probes) and goat anti-guinea-pig cyanine fluorescent dye (Cy3) (1:1000, Jackson Immuno Research, Cambridgeshire, UK) on a shaker for $1.5 \mathrm{~h}$ at RT. Nuclear staining was performed using DAPI (1:2000). All primary and secondary antibodies, as well as DAPI (Carl Roth), were diluted in PBS (1X) containing 5\% FBS and 1\% NGS. The coverslips with neurones were mounted on glass slides (Duran $76 \mathrm{~mm} \times 26 \mathrm{~mm}$, Carl Roth) with Immu-mount ${ }^{\circledR}$ (Shandon, Thermo Fisher). Immunofluorescent images for quantification of synaptic profiling between pre-and postsynaptic markers were captured using an Olympus IX83 invert microscope with DP80 camera (Olympus, Shinjuku, Japan) using the UPlanSApo $100 \times / 1.4$ oil objective with the following filter modules: U-F39002 AT-FITC for Alexa Fluor 488, U-F39004 AT-CY3 for Cy3, and U-FF for DAPI. Background correction, adjustment of brightness and contrast, and selection of regions of interest (ROI) were performed by CellSense software (Olympus, Shinjuku, Japan). Fluorescent images (Figure 1A) were captured with an inverted laser-scanning confocal microscope (SP8, Leica, Wetzlar, Germany) with a $63 \times / 1.4$ oil objective (zoom 3) using the Leica software. Images were taken using $488 \mathrm{~nm}$ and $564 \mathrm{~nm}$ lasers. Background correction, brightness, and contrast were adjusted by ImageJ software (NIH, Bethesda, MD, USA). Further processing of the images was carried out using Adobe Illustrator CC 2020.

\subsection{Lipidomic Study}

\subsubsection{Samples Collection for Lipid Analysis}

Hippocampal primary neurones (12 DIV) and glial cells were harvested and collected in Eppendorf ${ }^{\circledR}$ LoBind micro-centrifuge tubes (Eppendorf, Omnilab) after $3 \mathrm{~h}$ and $12 \mathrm{~h}$ with and without $A \beta_{(1-40)}$ and $A \beta_{(1-42)}$ treatment. The supernatant was discarded. Dishes were washed once with cold PBS (1X), neurones and glial cells collected in LoBind tubes after 2 min' centrifugation $(9391 \times g)$ at $4{ }^{\circ} \mathrm{C}$, the supernatant was discarded, and the pellets were snap-frozen and stored at $-80^{\circ} \mathrm{C}$. 
A
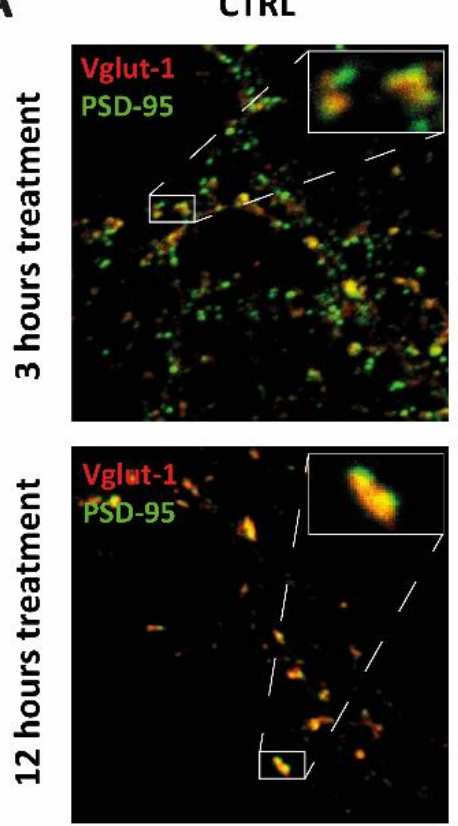

B

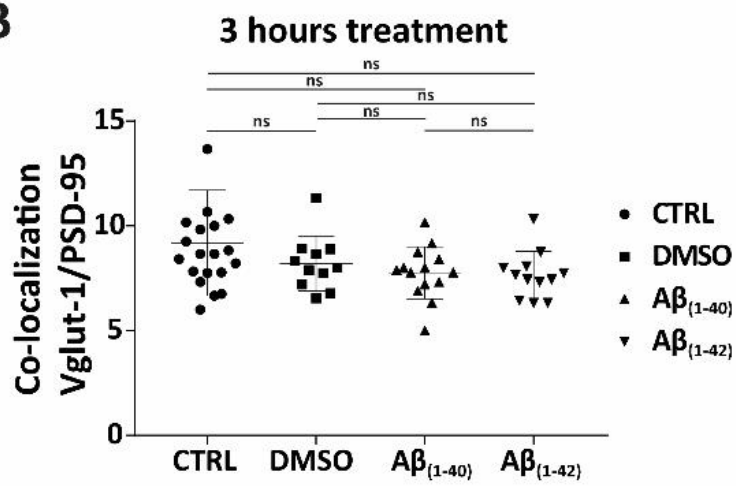

DMSO
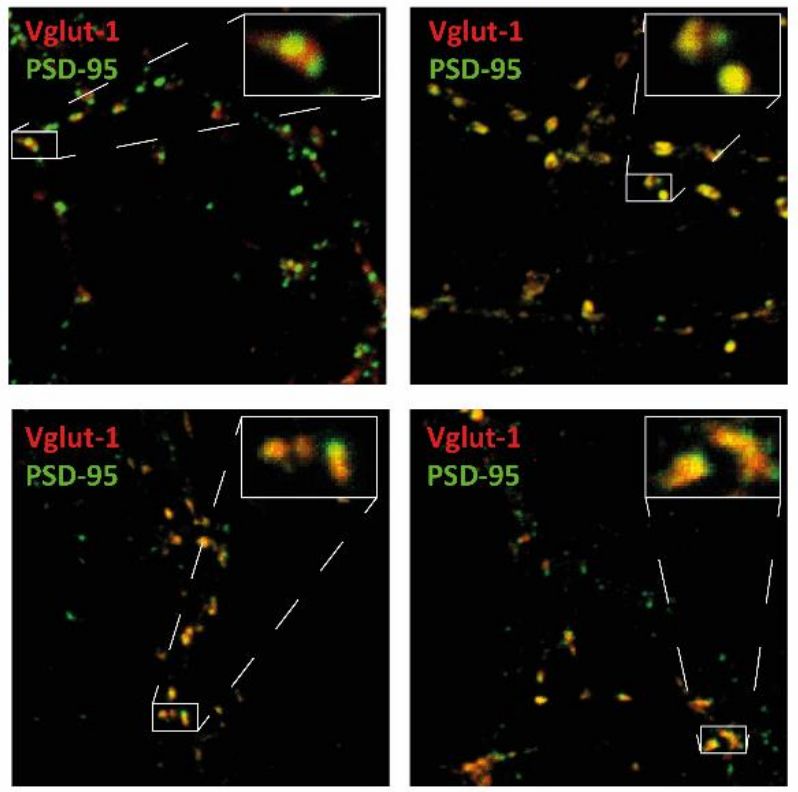

$A \boldsymbol{\beta}_{(1-40)}$

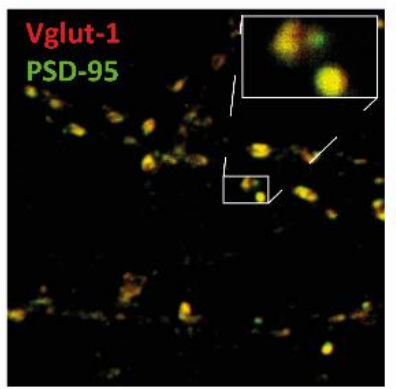

C

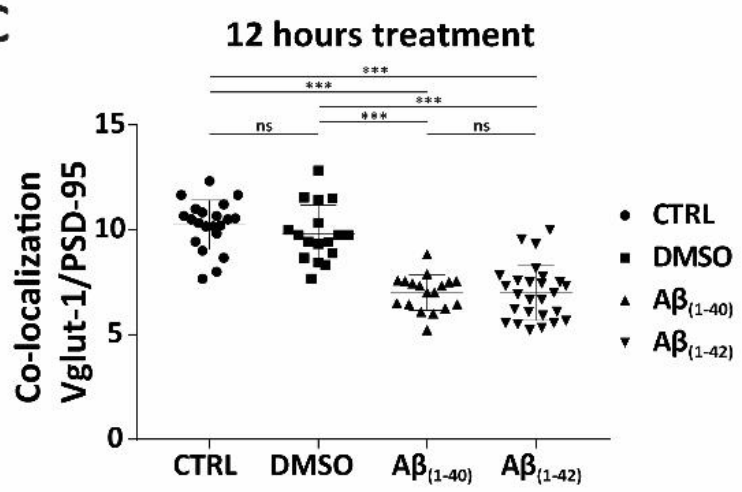

Figure 1. Synaptic loss of active synapses of $A \beta$ accumulation in hippocampal neurones. (A-C) The synaptic study showed the colocalisation of presynaptic (Vglut-1) and postsynaptic (PSD-95) markers, which was defined as active synapses, in hippocampal neurones at DIV12 for both control groups (CTRL and DMSO) and A $\beta$-treated groups $\left((1 \mu \mathrm{M}) \mathrm{A} \beta_{(1-40)}\right.$ and $\left.(1 \mu \mathrm{M}) \mathrm{A} \beta_{(1-42)}\right)$ at different time points $(3 \mathrm{~h}$ and $12 \mathrm{~h}$ ) of treatment (all groups from four independent cultures $(n=4))$. In the $3 \mathrm{~h}$ treatment, the following average number of neurones was counted in each group: CTRL $(n=12)$, $\operatorname{DMSO}(n=9), \mathrm{A} \beta_{(1-40)}(n=11)$ and $\mathrm{A} \beta_{(1-42)}(n=9)$. In the $12 \mathrm{~h}$ treatment, the following average number of neurones was counted in each group: CTRL $(n=14)$, DMSO $(n=13), \mathrm{A} \beta_{(1-40)}(n=13)$, and $\mathrm{A} \beta_{(1-42)}(n=17)$. For both $3 \mathrm{~h}$ and $12 \mathrm{~h}$ treatments, 3 ROI from each neurone was counted. (A) Representative confocal images of control groups and $A \beta$-treated groups of hippocampal neurones stained for both presynaptic (Vglut-1) and postsynaptic markers (PSD-95) are shown. There was a reduction in active synapses after $12 \mathrm{~h}$ of $\mathrm{A} \beta_{(1-40) \text { - }}$ and $\mathrm{A} \beta_{(1-42)}$-treated neurones compared to control groups. White boxes show enlargements of an example of defined active synapses for both control groups and $A \beta$-treated groups ( $3 \mathrm{~h}$ and $12 \mathrm{~h}$ ). (B,C) Quantification of active synapses from controland $A \beta$ _treated groups of hippocampal neurones. (B) No significant effect on active synapses was seen in A $\beta$-treated groups after $3 \mathrm{~h}$ ( 3 ROI of average counted cells; $n=10$, from four independent cultures $(n=4))$. (C) A significant reduction of active synapses was observed after $12 \mathrm{~h}$ of $\mathrm{A} \beta_{(1-40)^{-}}$ and $A \beta_{(1-42)}$-treated neurones compared to control groups. No significance (ns) was seen between CTRL and DMSO, nor between $A \beta_{(1-40)}$ - and $A \beta_{(1-42)}$-treated neurones (3 ROI of average counted cells; $n=14$, from four independent cultures $(n=4))$. ${ }^{* * *} p<0.0001$; scale bars represent $5 \mu \mathrm{m}$. The size of the ROI was $47 \mu \mathrm{m}^{2}$. 


\subsubsection{Lipid Extraction}

Hippocampal primary neurone (12 DIV) and glial-cell pellets were transferred by glass pipettes into transparent glass centrifuge tubes (Corning) containing chloroform $\left(\mathrm{CHCl}_{3}\right.$, SupraSolv ${ }^{\circledR}$, Merck, Darmstadt, Germany), methanol (LiChrosolv ${ }^{\circledR}$ HPLC gradient grade, Merck), and fuming hydrochloric acid 37\% (Rotipuran ${ }^{\circledR}$, p.a., ACS, ISO, Carl Roth) solutions supplemented with 1\% butylhydroxytoluol (BHT, $\geq 99 \%$, Carl Roth) and fractioned by pipetting up and down while the sample was on ice. Then, $1 \mu \mathrm{L}$ TopFluor lysophosphatidic acid (LPA) (702.58 g/mol, Avanti 810280P-1MG), was added per 1 million cells. The TopFluor LPA was dissolved in $1 \mathrm{~mL} \mathrm{CHCl}_{3}(1 \mathrm{mg} / \mathrm{mL})$. Then $\mathrm{CHCl}_{3}$ and water $\left(\mathrm{H}_{2} \mathrm{O}\right.$, Rotisolv ${ }^{\circledR}$ HPLC gradient grade, Carl Roth) were added, followed by vortexing and $30 \mathrm{~min}$ incubation in the dark at RT. Samples were centrifuged at $1260 \times g$ for $10 \mathrm{~min}$ at RT. Finally, the lipid phase was collected using a glass Pasteur pipette into a new glass vial (Thermo Fisher Scientific) and placed in a nitrogen chamber with $6 \% \mathrm{O}_{2}$ concentration, overnight in the dark. Until measurement, the samples were stored at $-20{ }^{\circ} \mathrm{C}$.

\subsubsection{High-Performance Thin-Layer Chromatography}

We used various external standards as references, such as 1,2-dioleoyl-sn-glycero3-phosphocholine (18:1 ( $\triangle 9$-Cis) PC (DOPC), Avanti 850375); 1,2-dioleoyl-sn-glycero-3phosphoethanolamine (18:1 ( $\triangle 9$-Cis) PE (DOPE), Avanti 850725); 1,2-dioleoyl-sn-glycero-3phospho-L-serine (18:1 PS (DOPS), Avanti 840035) for lipid classes of glycerophospholipids, and N-nervonoyl-D-erythro-sphingosylphosphorylcholine (24:1 SM, Avanti 860593) for lipid class of sphingolipids. Extracted lipid samples from the neuronal cell lysates were analysed by dilution in $12 \mu \mathrm{L} \mathrm{CHCl}_{3}$ for 1 million cells, using a Hamilton ${ }^{\circledR}$ syringe. The samples and external standard were vortexed and transferred by a Hamilton ${ }^{\circledR}$ syringe to a glass vial with glass micro-insert $(31 \times 6 \mathrm{~mm}$, Omnilab). The diluted samples and standards were sprayed band-shaped onto the silica gel plates (TLC silica gel $60 \mathrm{~F}_{254}(20 \times 10 \mathrm{~cm}$ plates), Merck) using the CAMAG automatic TLC sampler 4 (ATS 4). The sprayed bands were separated by capillary force, based on a polarity gradient in the mobile phase, using the CAMAG horizontal developing chamber. The mobile phase contained $\mathrm{CHCl}_{3}$, methanol, $\mathrm{H}_{2} \mathrm{O}$, and ammonia $\left(\mathrm{NH}_{3}, 32 \%\right.$ HiPerSolv ${ }^{\circledR}$ Chromanorm for HPLC, VWR). We performed visualisation (CAMAG TLC Visualizer 2) and scanning (CAMAG TLC Scanner 4) using the mercury lamp at a wavelength of $366 \mathrm{~nm}$ for the measurement of the fluorescent signal of the internal standard, Topfluor LPA, followed by a development step with a solution containing copper (II)-sulphate pentahydrate ( $\geq 99.5 \%$, p.a., ACS, ISO, Carl Roth), $\mathrm{H}_{2} \mathrm{O}$, ortho-phosphoric acid (85\%, Carl Roth), and methanol using the CAMAG Derivatizer. After derivatisation, the plate was placed for $1 \mathrm{~h}$ at $120^{\circ} \mathrm{C}$. Finally, the plates were visualised and scanned using a Tungsten lamp with a wavelength of $420 \mathrm{~nm}$. All data were processed by the CAMAG VisionCATS software 2.4, Adobe Photoshop CC 2020, and Adobe Illustrator CC 2020.

\subsubsection{Tandem Mass Spectrometry}

Lipid analyses were performed using lipid chromatography coupled to tandem mass spectrometry (tandem MS). Lipids were extracted as previously described [31]. Briefly, cells were resuspended in $1 \mathrm{~mL} \mathrm{H}_{2} \mathrm{O}$ and directly transferred into glass centrifuge tubes. After addition of $10 \mu \mathrm{L}$ of the internal standard $(30 \mu \mathrm{M}$ of C17-lysophosphatidylcholine (C17-LPC), C15-ceramide (C15-Cer), C17-sphingosine (C17-So), C34:0 phosphatidylcholine (PC 17:0/17:0), C17-sphingomyelin (C17-SM), C34:0 phosphatidylserine (PS 17:0/17:0), C17lysophosphatidylserine (C17-LPS), C17-lysophosphatidylethanolamine (C17-LPE), $10 \mu \mathrm{M}$ C17-sphingosine 1-phosphate (C17-So1P), all from Avanti Polar Lipids, Alabaster, AL, USA, and $1 \mathrm{mM}$ ergosterol from Merck), $200 \mu \mathrm{L} 6 \mathrm{~N} \mathrm{HCl}, 1 \mathrm{~mL}$ methanol and $2 \mathrm{~mL} \mathrm{CHCl}_{3}$ were also added. Samples were vigorously vortexed for $10 \mathrm{~min}$. After centrifugation at $1900 \times g$, the lower $\mathrm{CHCl}_{3}$ phase was collected. Extraction was repeated with an additional $2 \mathrm{~mL}$ of $\mathrm{CHCl}_{3}$, and the two $\mathrm{CHCl}_{3}$ phases were combined and evaporated using the SpeedVac RVC 2-25 CDplus (Christ, Osterode, Germany). Samples were resuspended in $100 \mu \mathrm{L}$ methanol: $\mathrm{CHCl}_{3}(4: 1 \mathrm{v} / \mathrm{v})$ and analysed using the Prominence high-performance liquid chromatogra- 
phy (HPLC) system (Shimadzu, Duisburg, Germany) with a $60 \mathrm{~mm} \times 2 \mathrm{~mm}$ MultoHigh 100 RP 18 column with $3 \mu \mathrm{m}$ particle size (CS-Chromatographie Service, Langerwehe, Germany), which was maintained at $50{ }^{\circ} \mathrm{C}$. The mobile phase A consisted of $1 \%(v / v)$ formic acid in $\mathrm{ddH}_{2} \mathrm{O}$, and the mobile phase $\mathrm{B}$ of $100 \%$ methanol. The column was equilibrated in $10 \% \mathrm{~B}$ with a flow rate of $0.5 \mathrm{~mL} \mathrm{~min}^{-1}$. The mobile phase switched to $100 \% \mathrm{~B}$ after sample injection. The flow rate increased linearly from $0.5 \mathrm{~mL} \mathrm{~min}^{-1}$ at $5 \mathrm{~min}$ to $1.0 \mathrm{~mL} \mathrm{~min} \mathrm{~m}^{-1}$ at $7 \mathrm{~min}$ and remained constant until $10 \mathrm{~min}$. Subsequently, the mobile phase changed to $10 \% \mathrm{~B}$, and the flow rate decreased linearly from $1.0 \mathrm{~mL} \mathrm{~min}^{-1}$ at $10 \mathrm{~min}$ to $0.5 \mathrm{~mL} \mathrm{~min}{ }^{-1}$ at $10.5 \mathrm{~min}$ and remained constant until the end of the program at $11.3 \mathrm{~min}$. Detection took place between 2 and $10 \mathrm{~min}$. The injection volume per sample was $10 \mu \mathrm{L}$, and samples were cooled to $4{ }^{\circ} \mathrm{C}$. The HPLC system was coupled to the API 2000 triple-quadrupole mass spectrometer (Sciex, Foster City, CA, USA) equipped either with an ESI or an APCI source (Table S2), both operating in positive mode under the following source parameters: source temperature $450{ }^{\circ} \mathrm{C}$, curtain gas 40 , collision gas "low", ion spray voltage 5500 , ion source gas 160 (APCI: 30), ion source gas 230 (APCI: 60). The analytical results were quantified with Analyst 1.6.2 (AB Sciex, Forster City, CA, USA) based on internal standard samples and an external standard curve.

\subsection{Data Analysis}

For quantification of our synaptic study, we counted active synapses on hippocampal neurones from 12 DIV. Synapses in hippocampal neurones were stained with antibodies specific for synaptic proteins (PSD-95, postsynaptic in green; Vglut-1, presynaptic in red). Only puncta with obvious PSD-95/Vglut-1 overlap (in yellow) were counted as active synapses [32]. We analysed three regions of interest $\left(\mathrm{ROI}=47 \mu \mathrm{m}^{2}\right)$ on each neurone for an average of $\geq 12$ neurones from four different cultures $(n=4)$ after both $3 \mathrm{~h}$ and $12 \mathrm{~h}$ of A $\beta$ treatment. In the $3 \mathrm{~h}$ treatment, the following average amount of neurones were counted in each group: CTRL $(n=12)$, DMSO $(n=9), \mathrm{A} \beta_{(1-40)}(n=11)$ and $\mathrm{A} \beta_{(1-42)}(n=9)$. For the $12 \mathrm{~h}$ treatment, the following average amount of neurones were counted in each group: CTRL $(n=14)$, DMSO $(n=13), \mathrm{A} \beta_{(1-40)}(n=13)$ and $\mathrm{A} \beta_{(1-42)}(n=17)$. Statistical analysis was performed using GraphPad Prism 7 (GraphPad Software, San Diego, CA, USA). Values were analysed for normal distribution using the Shapiro-Wilk test. As the data were not normally distributed, they were analysed by performing a Kruskal-Wallis test followed by a post hoc Dunn's multiple comparison test. All data are presented as mean + standard deviation (SD) and considered to be significant if $p<0.05(* * * p<0.0001)$. Tandem mass spectrometry data of three independent experiments $(n=3)$ from neurones and glial cells were further processed by GraphPad Prism 7, performing logarithmic 10 transformation, and plotted to our negative control (DMSO). This was because the raw data showed that a low concentration of DMSO (final concentration 0.03\%) showed an effect on both the lipid composition of glial cells and hippocampal primary neurones, as previously demonstrated [33]. Z-score transformation was performed, and data were plotted as heat maps for each lipid class.

\section{Results}

\subsection{Synaptic Loss after $A \beta_{(1-40)}$ and $A \beta_{(1-42)}$ Treatment}

To examine whether $A \beta$ species have a preferential early or late effect on the loss of active synapses, primary hippocampal neurones at 12 DIV were treated with $(1 \mu \mathrm{M}) \mathrm{A} \beta_{(1-40)}$ or $(1 \mu \mathrm{M}) \mathrm{A} \beta_{(1-42)}$ for $3 \mathrm{~h}$ and $12 \mathrm{~h}$. Active synapses were analysed by colocalisation of fluorescent markers recognizing vesicular glutamate transport 1 (Vglut-1) and postsynaptic density protein-95 (PSD-95) (Figure 1A-C). We quantified three ROI $\left(47 \mu \mathrm{m}^{2}\right)$ on the dendritic tree of the hippocampal neurones by examining the colocalisation dots (Figure $1 \mathrm{~A}$, white boxes) of a pre- and postsynaptic marker. No significant effect on active synapses was observed after $3 \mathrm{~h}$ treatment between our control groups (CTRL and DMSO) compared to $A \beta$-treated groups $\left(A \beta_{(1-40)}\right.$ and $\left.A \beta_{(1-42)}\right)$. After $12 \mathrm{~h}$, however, $A \beta$-treated groups showed a significant reduction in active synapses as compared to the control groups (Figure $1 \mathrm{~A}$ 
and Table 1). Both $3 \mathrm{~h}$ and $12 \mathrm{~h}$ DMSO treatments showed a small decrease in active synapses compared to the CTRL, but this was not significant (Figure 1B,C and Table 1). We observed no significant difference after $3 \mathrm{~h}$ and $12 \mathrm{~h}$ treatment between $\mathrm{A} \beta_{(1-40)}$ and $\mathrm{A} \beta_{(1-42)}$ treatments (Figure $1 \mathrm{~B}, \mathrm{C}$ and Table 1 ). However, $3 \mathrm{~h} \mathrm{~A} \beta_{(1-40)}$ and $\mathrm{A} \beta_{(1-42)}$ treatment showed a slight decrease in active synapse numbers as compared to our control groups, but this was not significant (Figure 1B,C and Table 1).

Table 1. List of the statistically adjusted $p$-value (from Figure 1B,C) between separate groups (CTRL, DMSO, $\mathrm{A} \beta_{(1-40)}$ and $\left.\mathrm{A} \beta_{(1-42)}\right)$ after $3 \mathrm{~h}$ and $12 \mathrm{~h}$ of treatment conditions. A Kruskal-Wallis test was performed, followed by a Dunn's multiple comparison test.

\begin{tabular}{ccc}
\hline & $\mathbf{3 ~ h}$ Treatment & $\mathbf{1 2} \mathbf{h}$ Treatment \\
\hline Kruskal-Wallis test & 0.0732 & $<0.0001$ \\
Dunn's multiple comparison test & adjusted $p$-value & adjusted $p$-value \\
CTRL vs. DMSO & $>0.9999$ & 0.6106 \\
CTRL vs. A $\beta_{(1-40)}$ & 0.3017 & $<0.0001$ \\
CTRL vs. A $\beta_{(1-42)}$ & 0.0867 & $<0.0001$ \\
DMSO vs. A $\beta_{(1-40)}$ & $>0.9999$ & $<0.0001$ \\
DMSO vs. A $\beta_{(1-42)}$ & $>0.9999$ & $<0.0001$ \\
A $\beta_{(1-40)}$ vs. A $\beta_{(1-42)}$ & $>0.9999$ & $>0.9999$ \\
\hline
\end{tabular}

3.2. Alterations in Cellular Lipids of Hippocampal Neurones and Glial Cells after $A \beta_{(1-40)}$ and $A \beta_{(1-42)}$ Treatment

3.2.1. Disruption in Cellular Lipids of Hippocampal Neurones and Glial Cells after A $\beta_{(1-40)}$ and $A \beta_{(1-42)}$ Treatment Using High-Performance Thin-Layer Chromatography (HPTLC)

Hippocampal neurones at 12 DIV and glial cells were treated with $A \beta_{(1-40)}$ and $A \beta_{(1-42)}$ for $3 \mathrm{~h}$ and $12 \mathrm{~h}$ to test whether $\mathrm{A} \beta$ species influence cellular lipids, whether that has a preference for a specific class of lipids, and to examine whether $A \beta_{(1-40)}$ and $A \beta_{(1-42)}$ have early effects on the lipid changes in these cells. Two different sets of analyses were performed: HPTLC and tandem MS. Lipids of hippocampal neurones and glial cells were extracted equally from our control groups (CTRL and DMSO) and A $\beta$-treated groups $\left(\mathrm{A} \beta_{(1-40)}\right.$ and $\left.\mathrm{A} \beta_{(1-42)}\right)$ after $3 \mathrm{~h}$ and $12 \mathrm{~h}$ of treatment. TopFluor lysophosphatidic acid (LPA) was used as the internal standard, to see whether the same amounts of lipids were extracted from each sample of control- and A $\beta$-treated groups (Figure S1A-D). To analyse which different lipid classes (e.g., sphingolipids and glycerophospholipids) were dysregulated, we showed HPTLC-derivatised copper (II)-sulphate images and their corresponding scanning profiles for hippocampal neurones and glial cells treated with $A \beta_{(1-40)}$ and $A \beta_{(1-42)}$ for $3 \mathrm{~h}$ and $12 \mathrm{~h}$ (Figure S2A-D). These images and profiles revealed changes in different lipid classes (e.g., sphingolipids and glycerophospholipids), which were in accordance with the external standards used (Figure S2, purple arrows and boxes). Each numbered purple arrow and box refers to external standards that could be detected from hippocampal neurones and glial cells after $3 \mathrm{~h}$ and $12 \mathrm{~h}$ of $A \beta_{(1-40)}$ and $A \beta_{(1-42)}$ treatment. The copper (II)-sulphate scanning profiles are shown to facilitate examination of the changes between control groups and $A \beta$-treated groups. The represented retention factor (Rf, Table S1) and arbitrary unit (AU, Table S1) are both based on the peak's end in the copper (II)sulphate scanning profiles. These show the changes in band intensity of the HPTLC copper (II)-sulphate images and correspond to the numbered labelled purple arrows and boxes (Figure S2). Our data showed small changes in sphingolipids and glycerophospholipids after $3 \mathrm{~h} \mathrm{~A} \beta_{(1-40)}$ and $A \beta_{(1-42)}$ treatment for both neurones (Figure S2A) and glial cells (Figure S2C), and large changes after $12 \mathrm{~h}$ of $A \beta_{(1-40)}$ and $A \beta_{(1-42)}$ treatment (Figure S2B,D).

3.2.2. Specific Identification of Various Lipid Isoforms after $A \beta_{(1-40)}$ and $A \beta_{(1-42)}$ Treatment from Hippocampal Neurones and Glial Cells Using Tandem Mass Spectrometry Analysis

To corroborate whether $A \beta_{(1-40)}$ and $A \beta_{(1-42)}$ preferentially influence specific sphingolipid or glycerophospholipids isoforms, we treated hippocampal neurones at DIV 12 
and glial cells for $3 \mathrm{~h}$ and $12 \mathrm{~h}$ with $\mathrm{A} \beta_{(1-40)}$ and $\mathrm{A} \beta_{(1-42)}$ and subsequently analysed them by tandem MS. Here, the characterisation of altered lipid isoforms for hippocampal neurones and glial cells after $3 \mathrm{~h}$ and $12 \mathrm{~h} \mathrm{~A} \beta_{(1-40)}$ and $A \beta_{(1-42)}$ treatment are shown, focussing on sphingolipids such as ceramides (Cer), dihydroceramides (DHCer), lactosylceramides (LacCer), monohexosylceramides (HexCer), sphingosine (So), sphinganine (Sa), sphingosine-1-phosphate (Sa1P), sphinganine-1-phosphate (So1P), sphingosylphosphorylcholine (SPC), sphingomylines (SM), dihydrosphingomylines (DHSM), and glycerophospholipids such as phosphatidylcholine (PC), lyso-phosphatidylcholine (LPC), lysophosphatidylethanolamine (LPE), lyso-phosphatidylglycerol (LPG), lyso-phosphatidylserine (LPS), Lyso-platelet-activating factor (Lyso-PAF) (Figures 2-4). All results are presented as a $\log _{10}$ transformation and were performed in triplicate. Furthermore, ratios between the $\mathrm{A} \beta$-treated groups and our negative control (DMSO) were calculated, setting the negative control (DMSO) to 0. After taking the ratios, the Z-score was taken for the total data set. Changes in lipid isoforms are shown as tendencies. This means that the red colours refer to an increase of lipid quantities and the green colour indicates a reduction compared to our negative control (DMSO) which was set to 0 as baseline parameter (Figures 2-4).

\section{Ceramides (Cer)}

Both hippocampal neurones and glial cells showed alterations in Cer isoforms after $3 \mathrm{~h}$ and $12 \mathrm{~h} \mathrm{~A} \beta_{(1-40)}$ and $\mathrm{A} \beta_{(1-42)}$ treatment (Figure 2). Neurones showed a reduction in C14 Cer after $3 \mathrm{~h} \mathrm{~A} \beta_{(1-40)}$ treatment. An increase of C14 Cer was observed after $3 \mathrm{~h}$ and $12 \mathrm{~h}$ of $A \beta_{(1-40)}$ and $A \beta_{(1-42)}$ treatment. Other ceramide isoforms (C16 Cer, C18:0 Cer, C20 Cer, $\mathrm{C} 22 \mathrm{Cer}, \mathrm{C} 24: 1 \mathrm{Cer})$ showed an increase in $3 \mathrm{~h} \mathrm{~A} \beta_{(1-40)}$-and $12 \mathrm{~h} \mathrm{~A} \beta_{(1-42)}$-treated neurons. $A \beta$-treated glial cells showed a strong increase after $3 \mathrm{~h} \mathrm{~A} \beta_{(1-40)}$ and $A \beta_{(1-42)}$ treatment for $\mathrm{C} 14$ Cer. After $12 \mathrm{~h}, \mathrm{~A} \beta_{(1-42)}$-treated glial cells showed a strong reduction compared to $\mathrm{A} \beta_{(1-40)}$ for $\mathrm{C} 14$ Cer. A weak reduction in C18:1 Cer for $3 \mathrm{~h} \mathrm{~A} \beta_{(1-42)}$ and $12 \mathrm{~h} \mathrm{~A} \beta_{(1-40)}$ (Figure 2) was also observed. Other ceramide isoforms (C16 Cer, C18:0 Cer, C20 Cer, C22 Cer, C24:1 Cer) showed a weak increase after $12 \mathrm{~h} \mathrm{~A} \beta_{(1-42)}$-treatment on glial cells. An increase was observed in $\mathrm{C} 24 \mathrm{Cer}$ after $3 \mathrm{~h} \mathrm{~A} \beta_{(1-40)}$ as well as after $3 \mathrm{~h}$ and $12 \mathrm{~h} \mathrm{~A} \beta_{(1-42)}$ in treated neurones. No changes were observed in $C 24$ Cer of $A \beta_{(1-40)}$ - and $A \beta_{(1-42)}$-treated glial cells (Figure 2).

\section{Dihydroceramides (DHCer)}

In $A \beta_{(1-42)}$-treated glial cells, C14 DHCer, C16 DHCer and C18:0 DHCer decreased after $3 \mathrm{~h}$ and increased after $12 \mathrm{~h}$ treatment. However, in glial cells C14 DHCer and C18:0 DHCer was increased after $3 \mathrm{~h}$ of $\mathrm{A} \beta_{(1-40)}$ treatment. After $3 \mathrm{~h} \mathrm{~A} \beta_{(1-40)^{-}}$and $\mathrm{A} \beta_{(1-42)^{-}}$ treatment on glial cells, a reduction in C20 DHCer and an increase in C22 DHCer was observed. After $12 \mathrm{~h}$ there was a decrease in $A \beta_{(1-40)^{-}}$and an slight increase in $A \beta_{(1-42)^{-}}$ treated glial cells. C24:1 DHCer showed a weak reduction after $3 \mathrm{~h} \mathrm{~A} \beta_{(1-40)}$ and $\mathrm{A} \beta_{(1-42)}$ treatment as well as an increase after $12 \mathrm{~h} \mathrm{~A} \beta_{(1-42)}$ treatment in glial cells. After $3 \mathrm{~h}$ and $12 \mathrm{~h} \mathrm{~A} \beta$ treatment, glial cells showed a decrease in C24 DHCer (Figure 2). A $\beta_{(1-40)}$ - and $\mathrm{A} \beta_{(1-42)}$-treated hippocampal neurones showed a specific decrease in C20 DHCer after $3 \mathrm{~h}$, and no changes after $12 \mathrm{~h} \mathrm{~A} \beta_{(1-40)}$ and $A \beta_{(1-42)}$ treatment. C22 DHCer showed a decrease in $3 \mathrm{~h} \mathrm{~A} \beta_{(1-40)}$ - and $12 \mathrm{~h} \mathrm{~A} \beta_{(1-42)}$-treated hippocampal neurones. An increase in C22 DHCer was seen in $3 \mathrm{~h} \mathrm{~A} \beta_{(1-42)}$ - and $12 \mathrm{~h} \mathrm{~A} \beta_{(1-40)}$-treated hippocampal neurones (Figure 2). Other Dihydroceramides isoforms (C14 DHCer, C16 DHCer, C24:1 DHCer, C24 DHCer) showed a weak increase in $3 \mathrm{~h} \mathrm{~A} \beta_{(1-40)}$-treated neurons. However, $3 \mathrm{~h} \mathrm{~A} \beta_{(1-42)}$ treatment showed a reduction in C14 DHCer, C16 DHCer, C24:1 DHCer, and increase in C24 DHCer (Figure 2). 


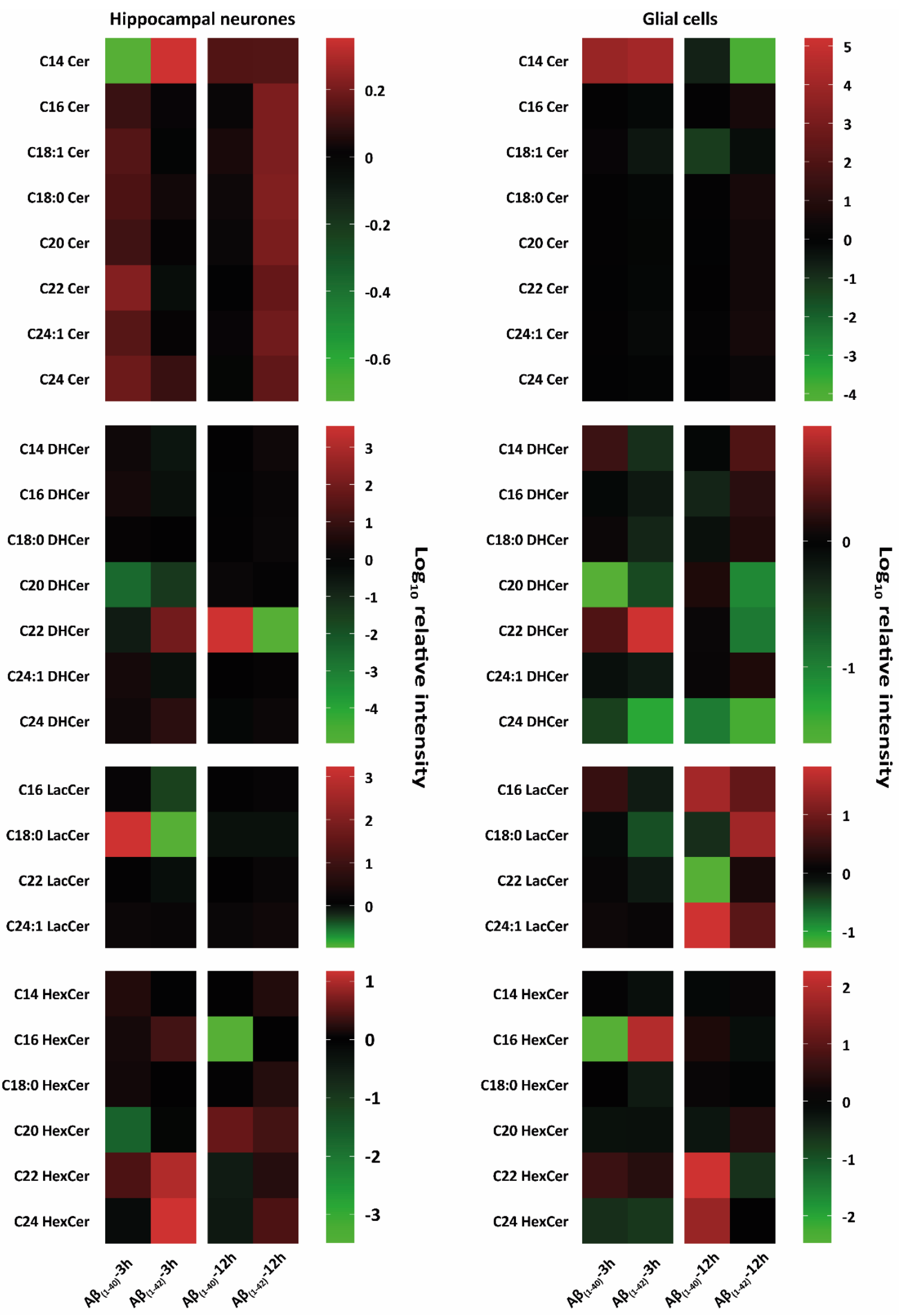

Figure 2. Heat-map-based mass spectrometry analysis of sphingolipid classes from hippocampal neurones and glial cells after $3 \mathrm{~h}$ and $12 \mathrm{~h} \mathrm{~A} \beta$ treatment. Here, we examined different sphingolipid 
isoforms: ceramides (Cer), dihydroceramides (DHCer), lactosylceramides (LacCer), and monohexosylceramides (HexCer) after $3 \mathrm{~h}$ and $12 \mathrm{~h}$ treatment with $(1 \mu \mathrm{M}) \mathrm{A} \beta_{(1-40)}$ and $(1 \mu \mathrm{M}) \mathrm{A} \beta_{(1-42)}$ of hippocampal neurons at DIV 12 and glial cells (all groups, from three independent experiments $(n=3))$. Changes of these lipid classes are shown as logarithmic $\left(\log _{10}\right)$ relative intensity (arbitrary unit); the green colour refers to a reduction, and the red colour refers to an increase of lipid levels compared to our negative control (DMSO), which was set to 0 as baseline. Both hippocampal neurones and glial cells showed an increased and reduced intensity of Cer, DHCer, LacCer, and HexCer isoforms after both $3 \mathrm{~h}$ and $12 \mathrm{~h} \mathrm{~A} \beta_{(1-40)}$ and $\mathrm{A} \beta_{(1-42)}$ treatment. Different changes in the lipid classes are shown between treated hippocampal neurones and glial cells. A $\beta$-treated hippocampal neurones showed prominent increases and decreases in Cer isoforms and LacCer and HexCer isoforms after $3 \mathrm{~h}$ and $12 \mathrm{~h}$ of $\mathrm{A} \beta_{(1-40)}$ and $\mathrm{A} \beta_{(1-42)}$ treatment. There was both a prominent intensity increase and a decrease of DHCer isoforms after $3 \mathrm{~h}$ and $12 \mathrm{~h}$ of $A \beta_{(1-40)}$ and $A \beta_{(1-42)}$ treatment. Glial cells showed prominent lipid changes of Cer, DHCer, LacCer, and HexCer isoforms after $3 \mathrm{~h}$ and $12 \mathrm{~h}$ of $\mathrm{A} \beta_{(1-40)}$ or $\mathrm{A} \beta_{(1-42)}$ treatment.

\section{Lactosylceramides (LacCer)}

Glial cells treated with $A \beta_{(1-40)}$ and $A \beta_{(1-42)}$ showed a reduction in all LacCer isoforms after $12 \mathrm{~h}$. In $3 \mathrm{~h} \mathrm{~A} \beta_{(1-42)}$-and $12 \mathrm{~h} \mathrm{~A} \beta_{(1-40)}$-treated glial cells, decreases in C18:0 LacCer and C22 LacCer and an increase after $12 \mathrm{~h} \mathrm{~A} \beta_{(1-42)}$ treatment were seen. In C16 LacCer and C24:1 LacCer an increase after $12 \mathrm{~h} \mathrm{~A} \beta_{(1-40)}$ and $\mathrm{A} \beta_{(1-42)}$ treatment on glial cells was seen. A reduction was observed in C16 LacCer after $3 \mathrm{~h} \mathrm{~A} \beta_{(1-40)}$ and a decrease after $3 \mathrm{~h}$ $A \beta_{(1-42)}$ treatment on glial cells. After $3 \mathrm{~h}, \mathrm{~A} \beta_{(1-40)}$-treated hippocampal neurones showed an increase in C18:0 LacCer. A decrease in C16 LacCer and C18 LacCer was seen in $3 \mathrm{~h}$ $\mathrm{A} \beta_{(1-42)}$-treated hippocampal neurons (Figure 2). A slight decrease was observed in C18:0 LacCer after $12 \mathrm{~h} \mathrm{~A} \beta_{(1-40)}$ and $\mathrm{A} \beta_{(1-42)}$-treatment on neurones as well as in C22 LacCer after $3 \mathrm{~h} \mathrm{~A} \beta_{(1-42)}$ treatment.

\section{Monohexosylceramides (HexCer)}

After $\mathrm{A} \beta_{(1-40)}$ treatment, $\mathrm{C} 16$ HexCer showed a strong reduction in $12 \mathrm{~h}$-treated hippocampal neurones and in 3 h-treated glial cells, whereas $3 \mathrm{~h} \mathrm{~A} \beta_{(1-42)}$-treated glial cells and $3 \mathrm{~h} A \beta_{(1-40)^{-}}$and $A \beta_{(1-42)}$-treated hippocampal neurones showed an increase (Figure 2). C22 HexCer and C24 HexCer showed strong increases after $12 \mathrm{~h} \mathrm{~A} \beta_{(1-40)}$ and decreases in $12 \mathrm{~h} \mathrm{~A} \beta_{(1-42)}$ for glial cells and a slight reduction in $12 \mathrm{~h} \mathrm{~A} \beta_{(1-40)}$ - and a strong increase in $12 \mathrm{~h} \mathrm{~A} \beta_{(1-42)}$-treated hippocampal neurones. After $3 \mathrm{~h}$ of $\mathrm{A} \beta_{(1-40)}$ - and $\mathrm{A} \beta_{(1-42)}$-treated hippocampal neurons and glial cells, a strong increase was seen in C22 HexCer. C24 HexCer showed an increase in 3 h A $\beta_{(1-40)}$ - and $A \beta_{(1-42)}$-treated glial cells as well as in $3 \mathrm{~h} \mathrm{~A} \beta_{(1-42)}$-treated hippocampal neurons. Slight increases were observed in C14 HexCer, C18:0 HexCer, and C20 HexCer after 3 h A $\beta_{(1-40)}$ treatment on hippocampal neurones. However, C14 HexCer showed an weak increase after $3 \mathrm{~h} \mathrm{~A} \beta_{(1-40)}$ and $12 \mathrm{~h}$ $\mathrm{A} \beta_{(1-42)}$ treatment on hippocampal neurones. A slight reduction was seen in $\mathrm{C} 14 \mathrm{DHCer}$ after $3 \mathrm{~h} \mathrm{~A} \beta_{(1-42)}$ and $12 \mathrm{~h} \mathrm{~A} \beta_{(1-40)}$ treatment on glial cells. C18:0 HexCer showed an increase after $3 \mathrm{~h} \mathrm{~A} \beta_{(1-40)}$ and $12 \mathrm{~h} \mathrm{~A} \beta_{(1-42)}$ on hippocampal neurones. A slight decrease in C18:0 HexCer was observed after $3 \mathrm{~h} \mathrm{~A} \beta_{(1-42)}$ treatment (Figure 2).

Sphingosine (So) and Sphingosine-1-Phosphate (So1P)

Hippocampal neurones and glial cells showed weak changes of d18:1 So after both $3 \mathrm{~h}$ and $12 \mathrm{~h} \mathrm{~A} \beta_{(1-40)}$ and $\mathrm{A} \beta_{(1-42)}$ treatments (Figure 3). There was a decrease in d18:1 So1P after $3 \mathrm{~h} \mathrm{~A} \beta_{(1-42)}$ treatment in hippocampal neurones and an increase after $12 \mathrm{~h}$ $\mathrm{A} \beta_{(1-42)}$ treatment in glial cells. A reduction in d18:1 So1P was also observed after $3 \mathrm{~h}$ and $12 \mathrm{~h} \mathrm{~A} \beta_{(1-40)}$ treatment of hippocampal neurons (Figure 3). An increase in d18:1 So1P for both $3 \mathrm{~h} \mathrm{~A} \beta_{(1-40)}$-treated glial cells and $12 \mathrm{~h} \mathrm{~A} \beta_{(1-42)}$-treated hippocampal neurones was observed (Figure 3). 


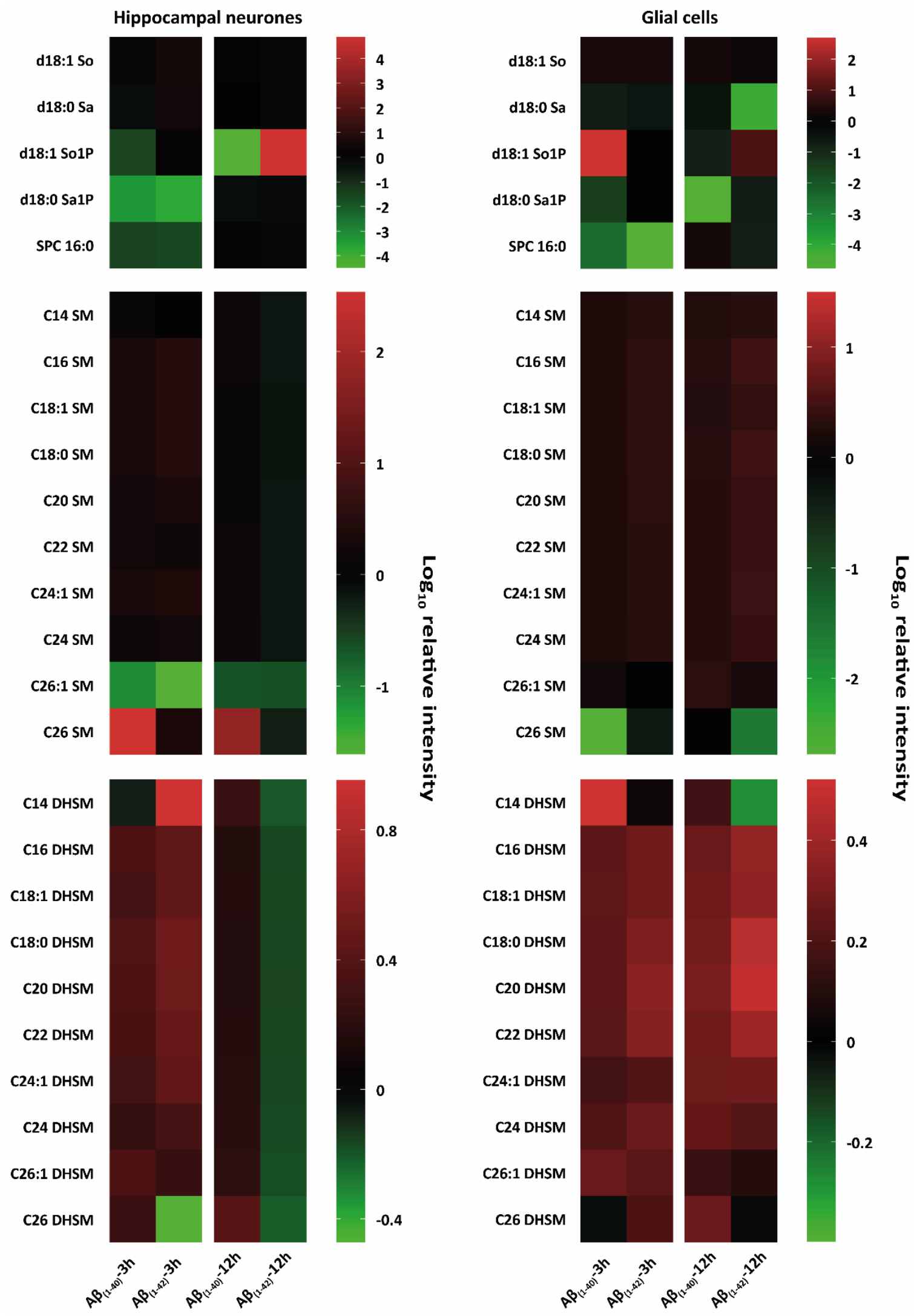

Figure 3. Heat-map-based mass spectrometry analysis of sphingophospholipid classes from hippocampal neurones and glial cells after $3 \mathrm{~h}$ and $12 \mathrm{~h} \mathrm{~A} \beta$ treatment. Here, we examined different 
sphingophospholipid isoforms; sphingosine (d18:1 So), sphinganine (d18:0 Sa), sphingosine-1phosphate (d18:1 So1P), sphinganine-1-phosphate (d18:1 Sa1P), sphingomyelines (SM) and dihydrosphingomyelines (DHSM) after $3 \mathrm{~h}$ and $12 \mathrm{~h}$ treatment with $(1 \mu \mathrm{M}) \mathrm{A} \beta_{(1-40)}$ and $(1 \mu \mathrm{M}) \mathrm{A} \beta_{(1-42)}$ hippocampal neurones at DIV 12 and glial cells (all groups, from three independent experiments $(n=3))$. Changes of these lipid classes are shown as logarithmic $\left(\log _{10}\right)$ relative intensity (arbitrary unit); the green colour refers to a reduction and the red colour refers to an increase in lipid levels compared to our negative control (DMSO), which was set to 0 as baseline. Major intensity changes in lipid classes of d18:1 So, d18:0 Sa, d18:1 So1P, d18:1 Sa1P after $3 \mathrm{~h}$ and $12 \mathrm{~h} \mathrm{~A} \beta_{(1-40)}$ and A $\beta_{(1-42)}$ treatment of hippocampal neurones and glial cells were observed. Specific lipid intensity changes after $A \beta_{(1-40)}$ and $A \beta_{(1-42)}$ treatment of hippocampal neurones of very long fatty acid SM compared to $A \beta$-treated glial cells were detected.

Sphinganine (Sa) and Sphinganine-1-Phosphate (Sa1P)

A prominent reduction was seen in d18:0 Sa for glial cells after $3 \mathrm{~h}$ and $12 \mathrm{~h} A \beta_{(1-40)}$ and $A \beta_{(1-42)}$ treatment (Figure 3). In hippocampal neurones d18:0 Sa was slightly increased after $3 \mathrm{~h} \mathrm{~A} \beta_{(1-40)}$ treatment and slightly reduced after $12 \mathrm{~h} \mathrm{~A} \beta_{(1-42)}$ treatment. A reduction was also observed in d18:0 Sa1 P after $3 \mathrm{~h} \mathrm{~A} \beta_{(1-40)^{-}}$and $A \beta_{(1-42)^{-t r e a t e d ~ h i p p o c a m p a l ~}}$ neurones, as well as $3 \mathrm{~h}$ and $12 \mathrm{~h} \mathrm{~A} \beta_{(1-40)}$-treated glial cells. No strong reduction was observed in d18:0 Sa1P after $12 \mathrm{~h} \mathrm{~A} \beta_{(1-40)}$ and $A \beta_{(1-42)}$ treatment of hippocampal neurones as well as in $3 \mathrm{~h} \mathrm{~A} \beta_{(1-42)}$-treated glial cells (Figure 3 ).

Sphingosylphosphorylcholine (SPC)

Both, hippocampal neurones and glial cells showed alterations in SPC 16:0 after $3 \mathrm{~h}$ $\mathrm{A} \beta_{(1-40)}$ and $\mathrm{A} \beta_{(1-42)}$ treatment. The most prominent decrease in SPC 16:0 was shown after $3 \mathrm{~h}$ of $\mathrm{A} \beta_{(1-40)}$ and $A \beta_{(1-42)}$ treatment for both hippocampal neurones and glial cells. $A$ decrease was also observed after $12 \mathrm{~h}$ of $\mathrm{A} \beta_{(1-42)}$ treatment for both hippocampal neurones and glial cells (Figure 3).

Sphingomyelines (SM)

All SM isoforms (C14 SM, C16 SM, C18:1 SM, C18:0 SM, C20 SM, C22 SM, C24:1 SM, C24 SM, C26:1 SM, and C26 SM) showed a slight increase after $3 \mathrm{~h} \mathrm{~A} \beta_{(1-40)}$ and $\mathrm{A} \beta_{(1-42)}$ treatment on hippocampal neurones, and glial cells after $3 \mathrm{~h}$ and $12 \mathrm{~h} \mathrm{~A} \beta_{(1-40)}$ and $\mathrm{A} \beta_{(1-42)}$ treatment (Figure 3). The most prominent reductions were observed in C26 SM for glial cells after $3 \mathrm{~h} \mathrm{~A} \beta_{(1-40)}$ and $12 \mathrm{~h} \mathrm{~A} \beta_{(1-42)}$ treatment and in C26:1 SM for hippocampal neurones after $3 \mathrm{~h}$ and $12 \mathrm{~h} \mathrm{~A} \beta_{(1-40)}$ and $\mathrm{A} \beta_{(1-42)}$ treatment. $3 \mathrm{~h}$ and $12 \mathrm{~h} \mathrm{~A} \beta_{(1-40)}$-treated hippocampal neurones showed a strong increase in C26 SM (Figure 3).

Dihydrosphingomyelines (DHSM)

Almost all DHSM isoforms (C14 DHSM, C16 DHSM, C18:1 DHSM, C18:0 DHSM, C20 DHSM, C22 DHSM, C24:1 DHSM, C24 DHSM, C26:1 DHSM and C26 DHSM) showed an increase after $3 \mathrm{~h} \mathrm{~A} \beta_{(1-40)}$ and $\mathrm{A} \beta_{(1-42)}$ and $12 \mathrm{~h} \mathrm{~A} \beta_{(1-40)}$ treatment, as well as a decrease after $12 \mathrm{~h} \mathrm{~A} \beta_{(1-42)}$ treatment of hippocampal neurones. The most prominent reduction in DHSM for hippocampal neurones was observed after $3 \mathrm{~h}$ in C14 DHSM after A $\beta_{(1-40)}$ treatment and C26 DHSM after $A \beta_{(1-42)}$ treatment, and for all DHSM isoforms after $12 \mathrm{~h} \mathrm{~A} \beta_{(1-42)}$ treatment (Figure 3). However, the most prominent increase in DHSM for hippocampal neurones was observed after $3 \mathrm{~h}$ in C14 DHSM after A $\beta_{(1-42)}$ treatment and C26 DHSM after $\mathrm{A} \beta_{(1-40)}$ treatment, and for all DHSM isoforms after $12 \mathrm{~h} \mathrm{~A} \beta_{(1-40)}$ treatment (Figure 3). Almost all DHSM isoforms (C14 DHSM, C16 DHSM, C18:1 DHSM, C18:0 DHSM, C20 DHSM, C22 DHSM, C24:1 DHSM, C24 DHSM, C26:1 DHSM, and C26 DHSM) from glial cells treated with $\mathrm{A} \beta$ were increased, whereas in glial cells, the most prominent increase are observed after $3 \mathrm{~h} \mathrm{~A} \beta_{(1-40)}$ treatment for C14 DHSM and after $12 \mathrm{~h} \mathrm{~A} \beta_{(1-42)}$ treatment for C18:0 DHSM, C20 DHSM, and C22 DHSM. Additionally, glial cells showed a prominent decrease in C14 DHSM after $12 \mathrm{~h} \mathrm{~A} \beta_{(1-42)}$ (Figure 3). 
Phosphatidylcholines (PC) and Lyso-Phosphatidylcholines (LPC)

A prominent decrease in PC (38:0) in hippocampal neurones after $3 \mathrm{~h} \mathrm{~A} \beta_{(1-40)}$ as well as $12 \mathrm{~h} \mathrm{~A} \beta_{(1-40)}$ and $\mathrm{A} \beta_{(1-42)}$ was observed, as well as an strong increase after $3 \mathrm{~h} \mathrm{~A} \beta_{(1-42)}$ treatment. All other PC isoforms (PC (28:0), PC (30:0), PC (30:1), PC (32:0), PC (32:1), PC (34:1), PC (34:2), PC (36:1), PC (36:2), PC (36:2), PC (36:3), PC (38:0), PC (38:1), PC (38:2), PC (38:3), PC (38:4)) showed a decrease in $3 \mathrm{~h} \mathrm{~A} \beta_{(1-40)}$ - and $12 \mathrm{~h} \mathrm{~A} \beta_{(1-40)}$-treated glial cells. Beside PC (28:0), a weak increase was observed after $12 \mathrm{~h} \mathrm{~A} \beta_{(1-42)}$ treatment in glial cells. The following PC isoforms (PC (28:0), PC (30:1), PC (32:0), PC (32:1), PC (34:1), PC (36:1), PC (38:0), PC (38:1), PC (38:2), PC (38:3)) were reduced after $3 \mathrm{~h} \mathrm{~A} \beta_{(1-40)}$ treatment of glial cells. Glial cells also showed a prominent increase in PC (36:0) after $3 \mathrm{~h} \mathrm{~A} \beta_{(1-40)}$ and $\mathrm{A} \beta_{(1-42)}$ treatment. No changes were observed in PC (38:0) after $12 \mathrm{~h} \mathrm{~A} \beta_{(1-42)}$ treatment of glial cells. LPC (20:0) showed a strong increase after $3 \mathrm{~h} \mathrm{~A} \beta_{(1-40)}$ treatment of hippocampal neurones and in $3 \mathrm{~h} \mathrm{~A} \beta_{(1-42)}$ - and $12 \mathrm{~h} \mathrm{~A} \beta_{(1-40)}$-treated glial cells (Figure 4). A prominent decrease was observed in LPC (20:0) in $3 \mathrm{~h} \mathrm{~A} \beta_{(1-40)}$ and $12 \mathrm{~h} \mathrm{~A} \beta_{(1-42)}$ treated glial cells and a weak decrease in $12 \mathrm{~h} \mathrm{~A} \beta_{(1-40)}$-treated hippocampal neurones (Figure 4).

Lyso-Phosphatidylethanolamine (LPE)

A reduction in all LPE isoforms (LPE (16:0), LPE (16:1), LPE (18:0), LPE (18:1), LPE (18:2), and LPE (20:4)) was shown in $3 \mathrm{~h} \mathrm{~A} \beta_{(1-40)^{-}}$and $A \beta_{(1-42)^{-}}$-treated hippocampal neurones. A slight decrease in all LPE isoforms (LPE (16:0), LPE (16:1), LPE (18:0), LPE (18:1), LPE (18:2), and LPE (20:4)) was shown in $3 \mathrm{~h} \mathrm{~A} \beta_{(1-42)}$-treated glial cells (Figure 4). An increase was observed in all LPE isoforms (LPE (16:0), LPE (16:1), LPE (18:0), LPE (18:1), LPE (18:2), and LPE (20:4)) in $12 \mathrm{~h} \mathrm{~A} \beta_{(1-42)}$-treated glial cells (Figure 4). $12 \mathrm{~h} \mathrm{~A} \beta_{(1-40)}$-treated hippocampal neurones showed an decrease in LPE (16:1), LPE (18:0), LPE (18:2), and LPE (20:4) as well as an increase in LPE (16:0), LPE (18:1) isoforms. An increase of LPE (16:0), LPE (18:1), and LPE (20:4)) was seen in $12 \mathrm{~h} \mathrm{~A} \beta_{(1-42)}$-treated hippocampal neurones.

Lyso-Phosphatidylglycerol (LPG)

LPG (14:1) and LPG (16:1) showed a reduction in $12 \mathrm{~h} \mathrm{~A} \beta_{(1-40)}$-treated hippocampal neurones. Glial cells showed a strong increase after $3 \mathrm{~h} \mathrm{~A} \beta_{(1-40)}$ and $A \beta_{(1-42)}$ treatment in LPG (14:1) and after $12 \mathrm{~h} \mathrm{~A} \beta_{(1-40)}$ treatment in LPG (16:1). In addition, LPG (16:1) showed a decrease after $3 \mathrm{~h} \mathrm{~A} \beta_{(1-40)}$ and $\mathrm{A} \beta_{(1-42)}$ treatment of glial cells (Figure 4).

Lyso-Phosphatidylserine (LPS)

LPS (18:2) showed an increase in $3 \mathrm{~h} \mathrm{~A} \beta_{(1-40)^{-}}$and $\mathrm{A} \beta_{(1-42)}$-treated glial cells as well as in $3 \mathrm{~h}$ and $12 \mathrm{~h} \mathrm{~A} \beta_{(1-40)}$-treated hippocampal neurones. A reduction was observed in $A \beta_{(1-42)}$-treated hippocampal neurons after $3 \mathrm{~h}$ and $12 \mathrm{~h}$ (Figure 4). A decrease was observed in LPS (18:0) after $3 \mathrm{~h} \mathrm{~A} \beta_{(1-40)}$ - and $\mathrm{A} \beta_{(1-42)}$-treated glial cells. LPS (16:0) was reduced in $3 \mathrm{~h} \mathrm{~A} \beta_{(1-40)}$-treated hippocampal neurones, as well as in $12 \mathrm{~h} \mathrm{~A} \beta_{(1-40)}$-treated glial cells (Figure 4).

Lyso-Platelet-Activating Factor (Lyso-PAF)

Lyso-PAF showed a reduction in $12 \mathrm{~h} \mathrm{~A} \beta_{(1-40)}$-treated glial cells, as well as in hippocampal neurones after $3 \mathrm{~h}$ and $12 \mathrm{~h}$, for both $A \beta_{(1-40)}$ and $A \beta_{(1-42)}$ treatment. A prominent increase of lyso-PAF was observed in $3 \mathrm{~h} \mathrm{~A} \beta_{(1-40)}$ - and $A \beta_{(1-42)}$-treated glial cells (Figure 4). 


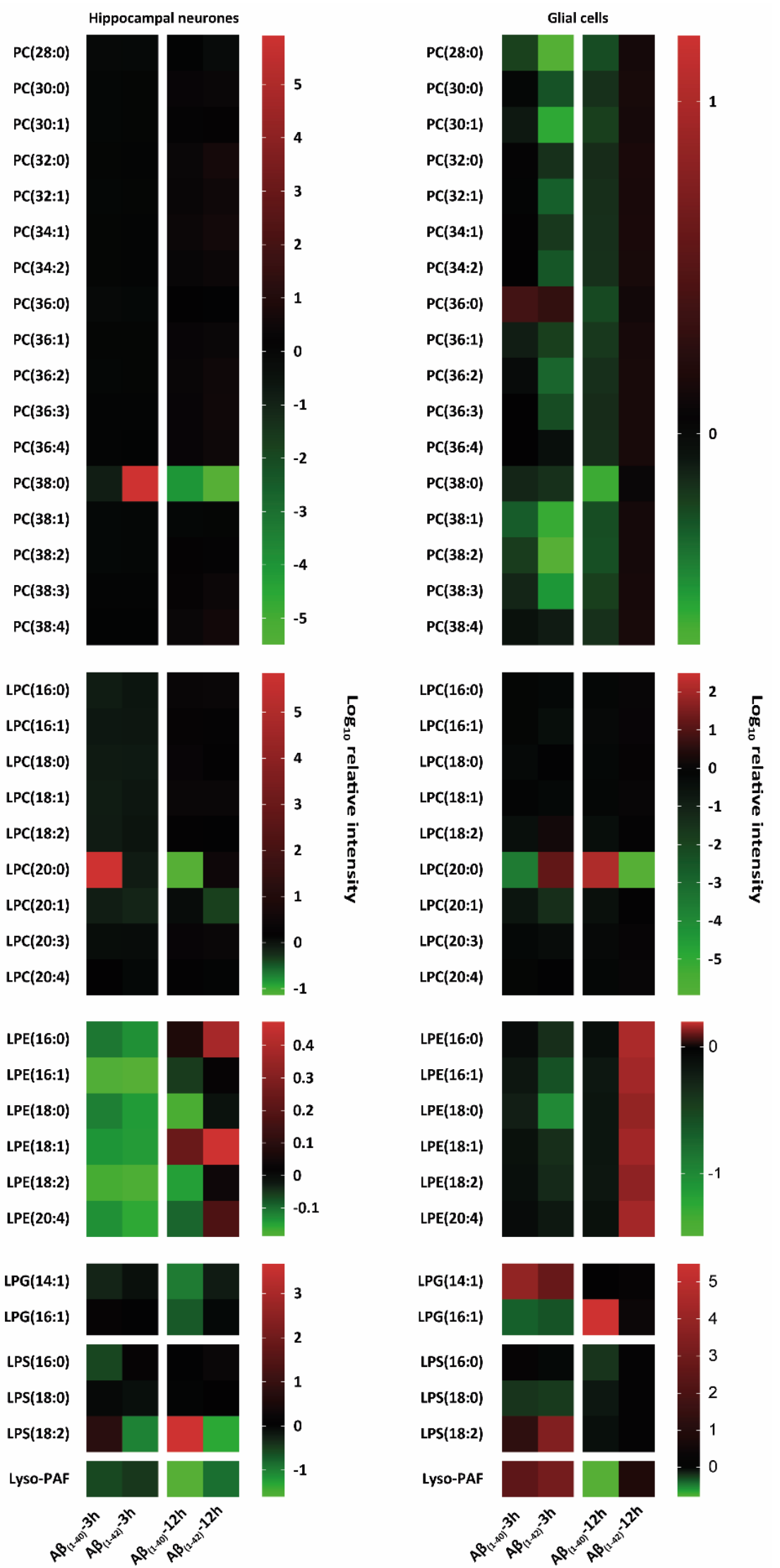

Figure 4. Heat map-based mass spectrometry analysis of glycerophospholipid classes from hippocampal neurones and glial cells after $3 \mathrm{~h}$ and $12 \mathrm{~h} \mathrm{~A} \beta$ treatment. Here, we examined different 
glycerophospholipids isoforms: phosphatidylcholine (PC), lyso-phosphatidylcholine (LPC), lysophosphatidylethanolamine (LPE), lyso-phosphatidylglycerol (LPG), lyso-phosphatidylserine (LPS), and lyso-platelet-activating factor (Lyso-PAF) after $3 \mathrm{~h}$ and $12 \mathrm{~h}$ treatment with $(1 \mu \mathrm{M}) \mathrm{A} \beta_{(1-40)}$ and $(1 \mu \mathrm{M}) \mathrm{A} \beta_{(1-42)}$ of hippocampal neurones at DIV 12 and glial cells (all groups, from three independent experiments $(n=3))$. Changes in these lipid classes are shown as logarithmic $\left(\log _{10}\right)$ relative intensity (arbitrary unit); the green colour refers to a reduction and the red colour refers to an increase in lipid levels compared to our negative control (DMSO), which was set to 0 as baseline. Hippocampal neurones specifically showed PC (38:0) intensity changes after $3 \mathrm{~h}$ and $12 \mathrm{~h} \mathrm{~A} \beta_{(1-40)}$ and $\mathrm{A} \beta_{(1-42)}$ treatment compared to an overall reduction in PC for $\mathrm{A} \beta_{(1-40)}$ and $\mathrm{A} \beta_{(1-42)}$-treated glial cells. LPC, LPG, LPS, and Lyso-PAF showed specific changes after $3 \mathrm{~h}$ and $12 \mathrm{~h} \mathrm{~A} \beta_{(1-40)}$ and $\mathrm{A} \beta_{(1-42)}$ treatment in both hippocampal neurones and glial cells.

\section{Discussion}

In this study, using different quantitative cellular techniques in different $A \beta$-treated primary brain cells, we showed for the first time that lipid profiles change after treatment and before synaptic loss was observed. We showed that human A $\beta$ species exogenously applied to primary neurones and glial cells influence the numbers of active synapses and led to lipid alterations in a time-dependent manner. We also demonstrated that $A \beta_{(1-40)}$ and $A \beta_{(1-42)}$ treatment have a specific-species dependent influence on the integrity of cellular lipids in hippocampal neurones and glial cells.

$A \beta_{(1-40)}$ and $A \beta_{(1-42)}$ induces synaptic loss only after $12 \mathrm{~h}$ of treatment.

Synaptic dysfunctions due to $A \beta$ accumulation are strongly associated with the cognitive disturbances of $A D$. The $A \beta$ species $A \beta_{(1-40)}$ and $A \beta_{(1-42)}$ are the major forms of amyloid $\beta$ peptides in the brain, whereby $A \beta_{(1-42)}$ seems to be more toxic than $A \beta_{(1-40)}[30,34,35]$. We found no selective influences of $A \beta_{(1-40)}$ or $A \beta_{(1-42)}$ on the loss of active synapses in cultured hippocampal neurones. Moreover, both $A \beta$ species induced synaptic loss after a $12 \mathrm{~h}$ treatment, whereas a $3 \mathrm{~h}$ treatment did not show effects on synapses either with $\mathrm{A} \beta_{(1-40)}$ or $A \beta_{(1-42)}$. Differences between these $A \beta$ species on the synapse alterations are dependent on the concentration and aggregated forms of $A \beta$ [30]. Moreover, Fu et al. (2017) [35] showed that the $A \beta_{(1-42)}$ oligomers have a moderate but significantly higher level of neurotoxicity, whereas monomers have the weakest neurotoxic effect ( $20 \%)$ on neuronal cells, without differences between $A \beta_{(1-40)}$ and $A \beta_{(1-42)}$. These results correspond to our findings on primary hippocampal neurones.

$A \beta_{(1-40)}$ and $A \beta_{(1-42)}$ differently influence cellular lipids before synaptic loss appears.

Previous studies have shown changes in different lipid classes and a correlation to AD pathology. Although we do not fully understand the connection between AD and lipid metabolism, there is more and more evidence that lipids could be a useful blood biomarker in the diagnostics of $\mathrm{AD}$, in addition to other risk factors [36,37]. Nevertheless, it is poorly understood which lipid isoforms are dysregulated on a cellular level. We showed here that changes in lipid composition in hippocampal neurones and glial cells occur early, even before synaptic loss becomes evident, and independently of the A $\beta$ species.

Our data indicate an increase of ceramides (especially C14 Cer) in glial cells and a reduction of these in hippocampal neurones. Both types of brain cells indicate an early reduction of specific dihydroceramides (C20 DHCer and C22 DHCer). These different amounts of lipids caused by $\mathrm{A} \beta$ could be a result of activated apoptotic-survival pathways and inflammatory activity due to their response to oxidative stress [38].

Glycosylated ceramides exhibited a reduced (C16 HexCer; C20 HexCer) or an increased level (C16 HexCer, C22 HexCer, C24 HexCer, C16 LacCer, C18 LacCer, C24:1 LacCer) for either hippocampal neurones or glial cells. Sphingomyelin (C26 SM) was upregulated in hippocampal neurones and downregulated in glial cells. It has been suggested that $A \beta_{(1-40)}$, $\mathrm{A} \beta_{(1-42)}$ and $\mathrm{A} \beta$-islet amyloid polypeptide concentrations lead to nSMase-mediated induction of apoptosis, resulting in neuronal cell death and $A \beta$-induced oxidative stress. $A \beta_{(1-40)}$ and $A \beta_{(1-42)}$ species and their oligomeric isoforms modify ceramide levels, which could explain the elevated nSMase and reduced cellular sphingomyelin activity [23,24,39-41]. 
In comparison with $A \beta_{(1-40)}$, it was shown that $A \beta_{(1-42)}$ directly activates nSMase by a $\gamma$-secretase-dependent mechanism, leading to increased ceramide levels [42].

Furthermore, we found an upregulation of d18:1 So1P in hippocampal neurones and glial cells after $3 \mathrm{~h}$ and $12 \mathrm{~h}$ treatment. An increase in So1P levels has been discussed in relation to $\mathrm{A} \beta$-induced toxicity in hippocampal neurones and glial cells in vitro and in vivo [43,44]. We also showed a reduction of SPC (16:0), Sa (d18:0 Sa), and Sa1P (d18:0 Sa1P) in hippocampal neurones and glial cells after $A \beta_{(1-40)}$ and $A \beta_{(1-42)}$ treatment. These reductions might be regulated by the increase of toxic $A \beta$ species' aggregates by enhancing $\beta$-secretase mediated pathways and the anti-inflammatory response in neuronal cells [45,46]. Furthermore, after $A \beta_{(1-40)}$ and $A \beta_{(1-42)}$ treatment we showed an early increase in specific isoforms of phospholipids in hippocampal neurones and lysophospholipids in hippocampal neurones and glial cells. Additionally, we verified that $\mathrm{A} \beta$-treated hippocampal neurones and glial cells showed a specific reduction in phospholipids (PC (38:0), LPC (20:0), all LPE, LPG, LPE (18:1), LPS (18:2) and Lyso-PAF) as well as a specific upregulation in phospholipids (PC (38:0), LPC (20:0), all LPE, LPG, LPE (18:1), LPS (18:2), and Lyso-PAF) after either $3 \mathrm{~h}$ or $12 \mathrm{~h} \mathrm{~A} \beta$ treatment. These glycerophospholipid alterations have been discussed in association with cytosolic phospholipase A2 hyperactivity in neuro-inflammatory responses and synapse-mediated $A \beta$ toxicity [31,47].

In conclusion, we found that after $A \beta_{(1-40)}$ or $A \beta_{(1-42)}$ treatment, levels of specific sphingolipid and glycerophospholipid isoforms change before there is any detectable loss of active synapses. No significant differences were seen between the effects of $A \beta_{(1-40)}$ and $A \beta_{(1-42)}$ species in the loss of active synapses. Our data contributes to a better understanding of the cellular influences of $A \beta$ species. It remains to be elucidated whether these influences of $A \beta$ species on changes in membrane lipid profiles could be useful as an early diagnostic biomarker in amyloidosis-related disorders.

Supplementary Materials: The following supporting information can be downloaded at: https:// www.mdpi.com/article/10.3390/ijms23042300/s1.

Author Contributions: Conceptualization, A.U.B.; Data curation, M.V.B., R.A.C. and M.G.; Formal analysis, M.V.B., N.B., R.A.C. and M.G.; Investigation, A.U.B.; Methodology, M.V.B., N.B., R.A.C. and M.G.; Supervision, A.U.B.; Validation, N.B.; Visualization, M.V.B.; Writing-original draft, M.V.B. and A.U.B.; Writing-review \& editing, M.V.B., N.B., R.A.C. and M.G. All authors have read and agreed to the published version of the manuscript.

Funding: This research was funded by H2020 MSCA-ITN-ETN BBDiag project under grant No. 721281.

Institutional Review Board Statement: These experiments were carried out in accordance with the institutional guidelines for animal welfare and approved by the "Niedersächsisches Landesamt für Verbraucherschutz und Lebensmittelsicherheit" (33.19-45502-04-18/2766).

Informed Consent Statement: Not applicable.

Acknowledgments: We acknowledge the financial support by H2020 MSCA-ITN-ETN BBDiag project under grant No. 721281 and Research Group Anatomy, School for Medicine and Health Science, Carl von Ossietzky University Oldenburg, Germany. In particular, Jennifer Sevecke-Rave and Isabel Groß are acknowledged for their excellent technical support in the laboratory. The authors also acknowledge the Fluorescence Microscopy Service Unit, Carl von Ossietzky University of Oldenburg, for the use of the imaging facilities.

Conflicts of Interest: The authors declare that they have no conflict of interest in the work performed. The sponsor had no role in design of the study, analysis, interpretation of data, in the writing of the manuscript, or in the decision to publish the results. 


Abbreviations
$\begin{array}{ll}\text { POPC } & \text { 1-Palmitoyl-2-oleoyl-sn-glycero-3-phosphocholine } \\ \text { DMPC } & \text { 1,2-dimyristoyl-sn-glycero-3-phosphocholine } \\ \text { DMPG } & \text { 1,2-Dimyristoyl-sn-glycero-3-phosphoglycerol } \\ \text { nSMase } & \text { Neutral isoform sphingomyelinase } \\ \text { aSMase } & \text { Acid sphingomyelinase }\end{array}$

\section{References}

1. Brothers, H.M.; Gosztyla, M.L.; Robinson, S.R. The Physiological Roles of Amyloid- $\beta$ Peptide Hint at New Ways to Treat Alzheimer's Disease. Front. Aging Neurosci. 2018, 10, 118. [CrossRef] [PubMed]

2. Pearson, H.A.; Peers, C. Physiological roles for amyloid beta peptides. J. Physiol. 2006, 575, 5-10. [CrossRef] [PubMed]

3. Kumar, A.; Singh, A.; Ekavali. A review on Alzheimer's disease pathophysiology and its management: An update. Pharmacol. Rep. 2015, 67, 195-203. [CrossRef] [PubMed]

4. Sosa, L.J.; Cáceres, A.; Dupraz, S.; Oksdath, M.; Quiroga, S.; Lorenzo, A. The physiological role of the amyloid precursor protein as an adhesion molecule in the developing nervous system. J. Neurochem. 2017, 143, 11-29. [CrossRef]

5. Walsh, D.M.; Klyubin, I.; Fadeeva, J.V.; Cullen, W.K.; Anwyl, R.; Wolfe, M.S.; Rowan, M.J.; Selkoe, D.J. Naturally secreted oligomers of amyloid beta protein potently inhibit hippocampal long-term potentiation in vivo. Nature 2002, 416, 535-539. [CrossRef]

6. Takahashi, R.H.; Milner, T.A.; Li, F.; Nam, E.E.; Edgar, M.A.; Yamaguchi, H.; Beal, M.F.; Xu, H.; Greengard, P.; Gouras, G.K. Intraneuronal Alzheimer abeta42 accumulates in multivesicular bodies and is associated with synaptic pathology. Am. J. Pathol. 2002, 161, 1869-1879. [CrossRef]

7. Walsh, D.M.; Selkoe, D.J. Deciphering the Molecular Basis of Memory Failure in Alzheimer's Disease. Neuron 2004, 44, 181-193. [CrossRef]

8. Lacor, P.N.; Buniel, M.C.; Chang, L.; Fernandez, S.J.; Gong, Y.; Viola, K.L.; Lambert, M.P.; Velasco, P.T.; Bigio, E.H.; Finch, C.E.; et al. Synaptic targeting by Alzheimer's-related amyloid beta oligomers. J. Neurosci. Off. J. Soc. Neurosci. 2004, 24, 10191-10200. [CrossRef]

9. Thal, D.R.; Schultz, C.; Dehghani, F.; Yamaguchi, H.; Braak, H.; Braak, E. Amyloid beta-protein (Abeta)-containing astrocytes are located preferentially near N-terminal-truncated Abeta deposits in the human entorhinal cortex. Acta Neuropathol. 2000, 100, 608-617. [CrossRef]

10. Gouras, G.K.; Tsai, J.; Naslund, J.; Vincent, B.; Edgar, M.; Checler, F.; Greenfield, J.P.; Haroutunian, V.; Buxbaum, J.D.; Xu, H.; et al. Intraneuronal Abeta42 accumulation in human brain. Am. J. Pathol. 2000, 156, 15-20. [CrossRef]

11. Hayashi, M.K.; Tang, C.; Verpelli, C.; Narayanan, R.; Stearns, M.H.; Xu, R.-M.; Li, H.; Sala, C.; Hayashi, Y. The postsynaptic density proteins Homer and Shank form a polymeric network structure. Cell 2009, 137, 159-171. [CrossRef] [PubMed]

12. Almeida, C.G.; Tampellini, D.; Takahashi, R.H.; Greengard, P.; Lin, M.T.; Snyder, E.M.; Gouras, G.K. Beta-amyloid accumulation in APP mutant neurons reduces PSD-95 and GluR1 in synapses. Neurobiol. Dis. 2005, 20, 187-198. [CrossRef] [PubMed]

13. Heras-Sandoval, D.; Ferrera, P.; Arias, C. Amyloid- $\beta$ protein modulates insulin signaling in presynaptic terminals. Neurochem. Res. 2012, 37, 1879-1885. [CrossRef] [PubMed]

14. Sokolow, S.; Luu, S.H.; Nandy, K.; Miller, C.A.; Vinters, H.V.; Poon, W.W.; Gylys, K.H. Preferential accumulation of amyloid-beta in presynaptic glutamatergic terminals (VGluT1 and VGluT2) in Alzheimer's disease cortex. Neurobiol. Dis. 2012, 45, 381-387. [CrossRef] [PubMed]

15. Takahashi, H.; Sekino, Y.; Tanaka, S.; Mizui, T.; Kishi, S.; Shirao, T. Drebrin-dependent actin clustering in dendritic filopodia governs synaptic targeting of postsynaptic density-95 and dendritic spine morphogenesis. J. Neurosci. Off. J. Soc. Neurosci. 2003, 23, 6586-6595. [CrossRef]

16. Takahashi, R.H.; Almeida, C.G.; Kearney, P.F.; Yu, F.; Lin, M.T.; Milner, T.A.; Gouras, G.K. Oligomerization of Alzheimer's beta-amyloid within processes and synapses of cultured neurons and brain. J. Neurosci. Off. J. Soc. Neurosci. 2004, 24, 3592-3599. [CrossRef]

17. Klementieva, O.; Willén, K.; Martinsson, I.; Israelsson, B.; Engdahl, A.; Cladera, J.; Uvdal, P.; Gouras, G.K. Pre-plaque conformational changes in Alzheimer's disease-linked A $\beta$ and APP. Nat. Commun. 2017, 8, 14726. [CrossRef]

18. Gouras, G.K.; Olsson, T.T.; Hansson, O. $\beta$-Amyloid peptides and amyloid plaques in Alzheimer's disease. Neurother. J. Am. Soc. Exp. NeuroTher. 2015, 12, 3-11. [CrossRef]

19. Hu, X.; Crick, S.L.; Bu, G.; Frieden, C.; Pappu, R.V.; Lee, J.-M. Amyloid seeds formed by cellular uptake, concentration, and aggregation of the amyloid-beta peptide. Proc. Natl. Acad. Sci. USA 2009, 106, 20324-20329. [CrossRef]

20. Chen, G.-F.; Xu, T.-H.; Yan, Y.; Zhou, Y.-R.; Jiang, Y.; Melcher, K.; Xu, H.E. Amyloid beta: Structure, biology and structure-based therapeutic development. Acta Pharmacol. Sin. 2017, 38, 1205-1235. [CrossRef]

21. Novo, M.; Freire, S.; Al-Soufi, W. Critical aggregation concentration for the formation of early Amyloid- $\beta$ (1-42) oligomers. Sci. Rep. 2018, 8, 1783. [CrossRef] [PubMed]

22. Ries, M.; Sastre, M. Mechanisms of A $\beta$ Clearance and Degradation by Glial Cells. Front. Aging Neurosci. 2016, 8, 160. [CrossRef] [PubMed] 
23. Grimm, M.O.W.; Grimm, H.S.; Pätzold, A.J.; Zinser, E.G.; Halonen, R.; Duering, M.; Tschäpe, J.-A.; Strooper, B.D.; Müller, U.; Shen, J.; et al. Regulation of cholesterol and sphingomyelin metabolism by amyloid- $\beta$ and presenilin. Nat. Cell Biol. 2005, 7, 1118-1123. [CrossRef] [PubMed]

24. He, X.; Huang, Y.; Li, B.; Gong, C.-X.; Schuchman, E.H. Deregulation of sphingolipid metabolism in Alzheimer's disease. Neurobiol. Aging 2010, 31, 398-408. [CrossRef] [PubMed]

25. Kim, Y.; Kim, C.; Jang, H.Y.; Mook-Jung, I. Inhibition of Cholesterol Biosynthesis Reduces $\gamma$-Secretase Activity and Amyloid- $\beta$ Generation. J. Alzheimer's Dis. JAD 2016, 51, 1057-1068. [CrossRef] [PubMed]

26. Puglielli, L.; Ellis, B.C.; Saunders, A.J.; Kovacs, D.M. Ceramide stabilizes beta-site amyloid precursor protein-cleaving enzyme 1 and promotes amyloid beta-peptide biogenesis. J. Biol. Chem. 2003, 278, 19777-19783. [CrossRef] [PubMed]

27. Venkateswaran, A.; Laffitte, B.A.; Joseph, S.B.; Mak, P.A.; Wilpitz, D.C.; Edwards, P.A.; Tontonoz, P. Control of cellular cholesterol efflux by the nuclear oxysterol receptor LXR alpha. Proc. Natl. Acad. Sci. USA 2000, 97, 12097-12102. [CrossRef]

28. Korshavn, K.J.; Satriano, C.; Lin, Y.; Zhang, R.; Dulchavsky, M.; Bhunia, A.; Ivanova, M.I.; Lee, Y.-H.; La Rosa, C.; Lim, M.H.; et al. Reduced Lipid Bilayer Thickness Regulates the Aggregation and Cytotoxicity of Amyloid- $\beta$. J. Biol. Chem. 2017, 292, 4638-4650. [CrossRef]

29. Niu, Z.; Zhao, W.; Zhang, Z.; Xiao, F.; Tang, X.; Yang, J. The molecular structure of Alzheimer $\beta$-amyloid fibrils formed in the presence of phospholipid vesicles. Angew. Chem. Int. Ed. Engl. 2014, 53, 9294-9297. [CrossRef]

30. Willén, K.; Sroka, A.; Takahashi, R.H.; Gouras, G.K. Heterogeneous Association of Alzheimer's Disease-Linked Amyloid- $\beta$ and Amyloid- $\beta$ Protein Precursor with Synapses. J. Alzheimer's Dis. JAD 2017, 60, 511-524. [CrossRef]

31. Sundaram, J.R.; Chan, E.S.; Poore, C.P.; Pareek, T.K.; Cheong, W.F.; Shui, G.; Tang, N.; Low, C.-M.; Wenk, M.R.; Kesavapany, S Cdk5/p25-Induced Cytosolic PLA2-Mediated Lysophosphatidylcholine Production Regulates Neuroinflammation and Triggers Neurodegeneration. J. Neurosci. 2012, 32, 1020-1034. [CrossRef] [PubMed]

32. Verstraelen, P.; Barriga, G.G.-D.; Verschuuren, M.; Asselbergh, B.; Nuydens, R.; Larsen, P.H.; Timmermans, J.-P.; De Vos, W.H. Systematic quantification of synapses in primary neuronal culture. Iscience 2020, 23, 101542. [CrossRef]

33. de Ménorval, M.-A.; Mir, L.M.; Fernández, M.L.; Reigada, R. Effects of Dimethyl Sulfoxide in Cholesterol-Containing Lipid Membranes: A Comparative Study of Experiments In Silico and with Cells. PLoS ONE 2012, 7, e41733. [CrossRef] [PubMed]

34. Bate, C.; Williams, A. Amyloid- $\beta(1-40)$ inhibits amyloid- $\beta(1-42)$ induced activation of cytoplasmic phospholipase A2 and synapse degeneration. J. Alzheimer's Dis. JAD 2010, 21, 985-993. [CrossRef] [PubMed]

35. Fu, L.; Sun, Y.; Guo, Y.; Chen, Y.; Yu, B.; Zhang, H.; Wu, J.; Yu, X.; Kong, W.; Wu, H. Comparison of neurotoxicity of different aggregated forms of A $\beta 40, \mathrm{~A} \beta 42$ and A $\beta 43$ in cell cultures. J. Pept. Sci. Off. Publ. Eur. Pept. Soc. 2017, 23, 245-251. [CrossRef] [PubMed]

36. Agarwal, M.; Khan, S. Plasma Lipids as Biomarkers for Alzheimer's Disease: A Systematic Review. Cureus 2020, 12, 1. [CrossRef]

37. Ceccom, J.; Loukh, N.; Lauwers-Cances, V.; Touriol, C.; Nicaise, Y.; Gentil, C.; Uro-Coste, E.; Pitson, S.; Maurage, C.A.; Duyckaerts, C. Reduced sphingosine kinase-1 and enhanced sphingosine 1-phosphate lyase expression demonstrate deregulated sphingosine 1-phosphate signaling in Alzheimer's disease. Acta Neuropathol. Commun. 2014, 2, 1-10. [CrossRef]

38. Jazvinšćak Jembrek, M.; Hof, P.R.; Šimić, G. Ceramides in Alzheimer's Disease: Key Mediators of Neuronal Apoptosis Induced by Oxidative Stress and A $\beta$ Accumulation. Oxidative Med. Cell. Longev. 2015, 2015, 346783. [CrossRef]

39. Qi, X.-L.; Xiu, J.; Shan, K.-R.; Xiao, Y.; Gu, R.; Liu, R.-Y.; Guan, Z.-Z. Oxidative stress induced by beta-amyloid peptide(1-42) is involved in the altered composition of cellular membrane lipids and the decreased expression of nicotinic receptors in human SH-SY5Y neuroblastoma cells. Neurochem. Int. 2005, 46, 613-621. [CrossRef]

40. Malaplate-Armand, C.; Florent-Béchard, S.; Youssef, I.; Koziel, V.; Sponne, I.; Kriem, B.; Leininger-Muller, B.; Olivier, J.-L.; Oster, T.; Pillot, T. Soluble oligomers of amyloid-beta peptide induce neuronal apoptosis by activating a cPLA2-dependent sphingomyelinase-ceramide pathway. Neurobiol. Dis. 2006, 23, 178-189. [CrossRef]

41. Zhang, Y.; Ranta, F.; Tang, C.; Shumilina, E.; Mahmud, H.; Föller, M.; Ullrich, S.; Häring, H.-U.; Lang, F. Sphingomyelinase dependent apoptosis following treatment of pancreatic beta-cells with amyloid peptides Abeta(1-42) or IAPP. Apoptosis Int. J. Program. Cell Death 2009, 14, 878-889. [CrossRef] [PubMed]

42. Michno, W.; Kaya, I.; Nyström, S.; Guerard, L.; Nilsson, K.P.R.; Hammarström, P.; Blennow, K.; Zetterberg, H.; Hanrieder, J. Multimodal Chemical Imaging of Amyloid Plaque Polymorphism Reveals A $\beta$ Aggregation Dependent Anionic Lipid Accumulations and Metabolism. Anal. Chem. 2018, 90, 8130-8138. [CrossRef] [PubMed]

43. Czubowicz, K.; Cieślik, M.; Pyszko, J.; Strosznajder, J.B.; Strosznajder, R.P. Sphingosine-1-Phosphate and Its Effect on Glucose Deprivation/Glucose Reload Stress: From Gene Expression to Neuronal Survival. Mol. Neurobiol. 2015, 51, 1300-1308. [CrossRef] [PubMed]

44. Zhong, L.; Jiang, X.; Zhu, Z.; Qin, H.; Dinkins, M.B.; Kong, J.-N.; Leanhart, S.; Wang, R.; Elsherbini, A.; Bieberich, E.; et al. Lipid transporter Spns2 promotes microglia pro-inflammatory activation in response to amyloid-beta peptide. Glia 2019, 67, 498-511. [CrossRef] [PubMed]

45. Yi, H.; Lee, S.J.; Lee, J.; Myung, C.-S.; Park, W.-K.; Lim, H.-J.; Lee, G.H.; Kong, J.Y.; Cho, H. Sphingosylphosphorylcholine attenuated $\beta$-amyloid production by reducing BACE1 expression and catalysis in PC12 cells. Neurochem. Res. 2011, 36, 2083-2090. [CrossRef] [PubMed]

46. Park, M.K.; Lee, C.H. Role of Sphingosylphosphorylcholine in Tumor and Tumor Microenvironment. Cancers 2019, 11, 1696 [CrossRef]

47. Moses, G.S.; Jensen, M.D.; Lue, L.-F.; Walker, D.G.; Sun, A.Y.; Simonyi, A.; Sun, G.Y. Secretory PLA2-IIA: A new inflammatory factor for Alzheimer's disease. J. Neuroinflamm. 2006, 3, 28. [CrossRef] 